\title{
NATO military interventions in Kosovo, Libya, Afghanistan and their impact on relations with Russia after the Cold War
}

\author{
Dovydas Rogulis \\ West Virginia University
}

Follow this and additional works at: https://researchrepository.wvu.edu/etd

\section{Recommended Citation}

Rogulis, Dovydas, "NATO military interventions in Kosovo, Libya, Afghanistan and their impact on relations with Russia after the Cold War" (2014). Graduate Theses, Dissertations, and Problem Reports. 251. https://researchrepository.wvu.edu/etd/251

This Thesis is protected by copyright and/or related rights. It has been brought to you by the The Research Repository @ WVU with permission from the rights-holder(s). You are free to use this Thesis in any way that is permitted by the copyright and related rights legislation that applies to your use. For other uses you must obtain permission from the rights-holder(s) directly, unless additional rights are indicated by a Creative Commons license in the record and/ or on the work itself. This Thesis has been accepted for inclusion in WVU Graduate Theses, Dissertations, and Problem Reports collection by an authorized administrator of The Research Repository @ WVU. For more information, please contact researchrepository@mail.wvu.edu. 


\title{
NATO MILITARY INTERVENTIONS IN KOSOVO, LIBYA, AFGHANISTAN AND THEIR IMPACT ON RELATIONS WITH RUSSIA AFTER THE COLD WAR
}

\author{
Dovydas Rogulis
}

Thesis submitted

to the Eberly College of Arts and Sciences at West Virginia University

in partial fulfillment of the requirements

for the degree of

Master of Arts in

History

\begin{abstract}
Robert Blobaum, Chair, Ph.D.
James Siekmeier, Ph.D.

Elizabeth Fones-Wolf, Ph.D.
\end{abstract}

Department of History

Morgantown, West Virginia

2014

Keywords: NATO, Russia, military interventions, Kosovo, Libya, Afghanistan, geopolitics, international relations, geopolitical discourses.

Copyright Dovydas Rogulis 


\section{Abstract \\ NATO MILITARY INTERVENTIONS IN KOSOVO, LIBYA, AFGHANISTAN AND \\ THEIR IMPACT ON RELATIONS WITH RUSSIA AFTER THE COLD WAR}

\section{Dovydas Rogulis}

This thesis seeks to find out how NATO military interventions in Kosovo, Libya and Afghanistan have negatively affected relations with Russia. In order to achieve the aim and hypothesis of the study, the critical geopolitical approach is chosen as a theoretical framework.

The schematic critical geopolitics conceptualization of Gearóid Ó. Tuathail is used as the method of research. This thesis mostly pays attention to three essential parts of the critical geopolitics: "formal geopolitics" (analyses of think tanks, specialists, etc.), "practical geopolitics" (the decisions of policy makers, official statements, documents, strategies and speeches) and "popular geopolitics" (media discourse and opinion surveys). The combination of these three elements allows for a determination of certain NATO and Russian geopolitical discourses towards crises in Kosovo, Libya and Afghanistan. In relation to these crises, NATO and Russian geopolitical discourses are assessed from very positive, positive, neutral, to negative and very negative. This approach provides an opportunity to see how both sides have scripted these crises and how over the long term NATO's military interventions in Kosovo, Libya and Afghanistan have influenced relations with Russia and affected the international order.

Moreover, descriptive method, discourse analysis and a comparative approach are used to scrutinize Russian and NATO's geopolitical discourses towards crises. The analyses of NATO and Russian geopolitical discourses show the hypothesis that different NATO and Russian geopolitical discourses towards crises in Kosovo, Libya and Afghanistan have led to reciprocal accruing disagreements is only partly correct. The crisis of Kosovo in $\mathbf{2 0 0 8}$ marked the end of the Russian flexible policy towards NATO and a new beginning of a permanently hostile geopolitical discourse against NATO in Europe. NATO military interventions in Kosovo, Libya and Afghanistan have negatively affected relations with Russia, mostly in Europe. Mutual cooperation and diplomatic disputes towards crises in Libya and Afghanistan are of minor importance in comparison with NATO-Russian relations on the European continent. Consequently, Russia concentrates most of its geopolitical attention towards Europe. 


\section{Acknowledgements}

For those who always believe in what I do. 


\section{Table of contents}

Acknowledgements ............................................................................................. iii

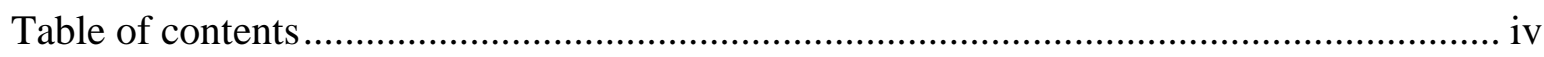

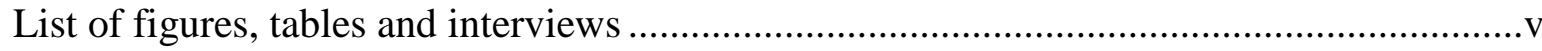

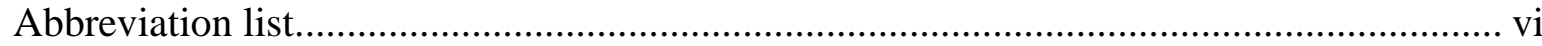

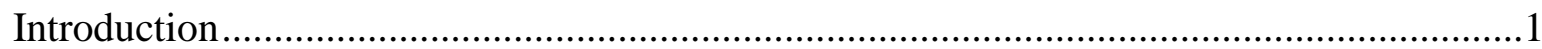

1. Theoretical Overview of the Critical Geopolitics .........................................................

1.1. The development of the geopolitical approach .................................................... 3

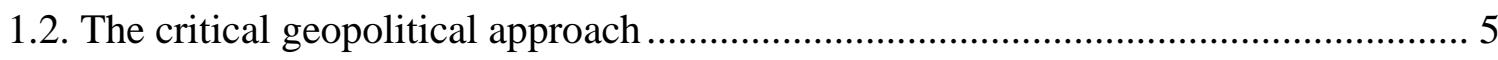

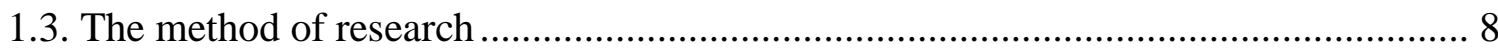

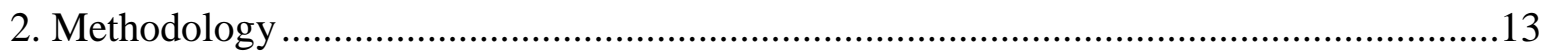

3. Case Studies in Times of Crisis .............................................................................. 18

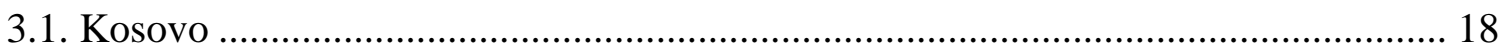

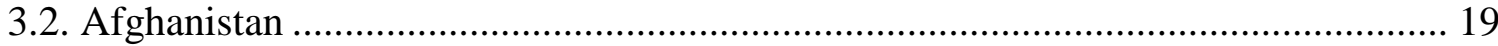

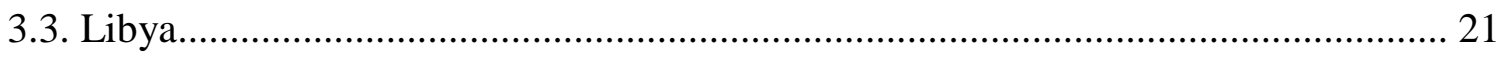

4. Geopolitical Discourses during Crises .................................................................23

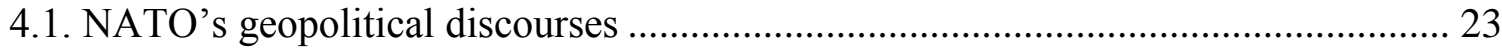

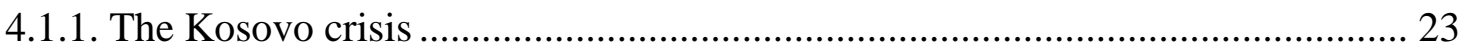

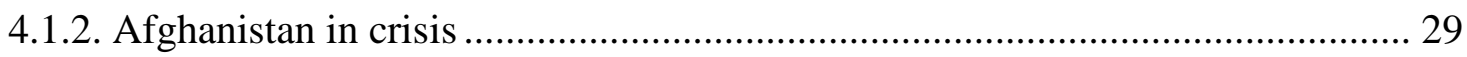

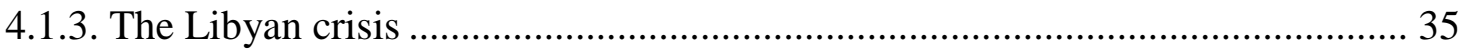

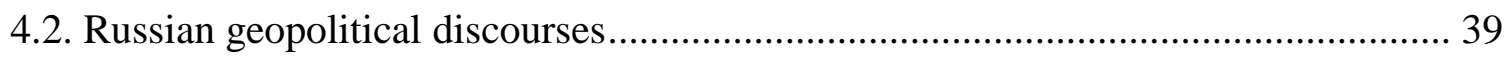

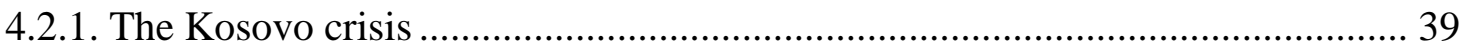

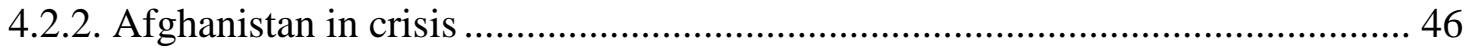

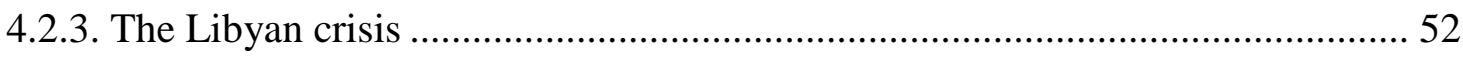

5. The Interaction of Geopolitical Discourses .....................................................55

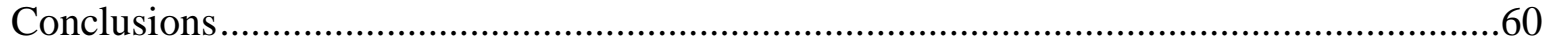

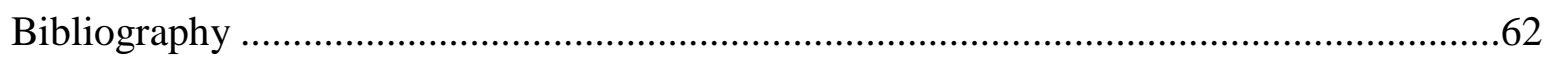

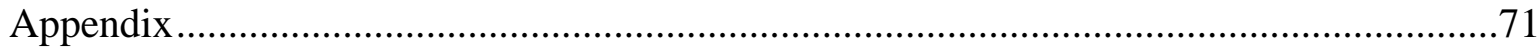




\section{List of figures, tables and interviews}

\section{Maps:}

Map Nr. 1 H. J. Mackinder's The World-Island and the Heartland

Map Nr. 2 NATO transition supply roads to Afghanistan

\section{Tables:}

Table Nr. 1 Difference between Modern and Critical geopolitics 5

Table Nr. 2 Geopolitics: a critical geopolitics conzeptualization 8

Table Nr. 3 The western media`s coverage of 'terrorism' and the 'terrorism in Afghanistan' 31

Table Nr. 4 Public opinion towards the crisis in Libya 38

Table Nr. 5 NATO's and the Russian geopolitical discourses towards crisis 55

Table Nr. 6 Casualties of NATO forces in Afghanistan $\quad 80$

\section{Interviews:}

Interview Nr. 1 Interview with the Senior Counselor Denis Gonchar in the Russian Embassy in

Washington D.C. (13.02.2014)

Interview Nr. 2 Interview with Dr. Ieva Karpaviciute, a special Lithuanian attaché to NATO HQ

Interview Nr. 3 Interview with the senior expert Vadim Volovoj from the Centre of Geopolitical Studies (02.03.2014)

Interview Nr. 4 Interview with Professor Boris Barkanov, a lecturer in Political Science at West Virginia University (05.03.2014) 


\author{
Abbreviation list \\ ACT - Allied Command Transformation \\ AWACS - Airborne Warning and Control System \\ $\mathrm{BBC}$ - British Broadcasting Corporation \\ CIS - Commonwealth of Independent States \\ CNN - Cable News Network (one of the media groups in the US) \\ CSTO - Collective Security Treaty Organization \\ FRY - Former Republic of Yugoslavia \\ ISAF - International Security Assistance Force \\ KFOR - Kosovo Force \\ KLA - Kosovo Liberation Army \\ MENA - Middle East and North Africa \\ NAC - North Atlantic Council \\ NATO - North Atlantic Treaty Organisation \\ OAF - Operation Allied Force \\ SHAPE - Supreme Headquarters Allied Powers Europe \\ UN - United Nations \\ UN SC - United Nations Security Council \\ WMD - Weapons of Mass Destruction
}




\section{Introduction}

We [NATO member states] are confronted with a new, radically altered, strategic environment. Terrorism, weapons of mass destruction and "failed states" all confront us with challenges that are different from anything we have witnessed in the past - Jaap de Hoop Scheffer, the NATO Secretary General (2004).

After the Cold War new geopolitical ideas started to appear in academic discourse. Classical and Modern geopolitics are no longer adequate to explain the changes and transformations of the World since the 1990s. Geography as a fundamental factor of geopolitics lost its significance. Countries with the same ideologies and values started to (re)unite and (re)establish regional or even global organizations and alliances. In 1949 NATO was established as a military defense alliance which unified western countries against the Soviet menace. After the collapse of the Soviet Union, the external threat to NATO also disappeared. Consequently, NATO had to search for a new vision.

During the post-Cold War period NATO has been transformed from a closed military alliance to a mobile crisis manager. In the last twenty years NATO has become a sui generis Alliance much different from its 1949 design to deter the Soviet threat. According to the NATO concept in 2010, the alliance seeks to prevent crises, manage conflicts and stabilize post-conflict situations, including by working more closely NATO's international partners, most importantly the United Nations and the European Union.

After the Cold War NATO's transformation was significant in several respects, the Alliance expanded and incorporated new allies all around Europe; it implemented new overseas missions outside its boundaries; it expanded its capabilities from peacekeeping and reconstruction missions to humanitarian aid and the fight against piracy and global terrorism. In addition, in the last two decades NATO transformed its military and modernized its effectiveness.

During the Cold War NATO was mostly based on huge conscript armies and air power, however, in the late twentieth and early twenty-first centuries confronted by new global challenges the Alliance transformed its military to small highly skilled units, which could be rapidly deployed using advanced technologies. Therefore, changes in the international system 
were a fundamental factor that propelled NATO's new political and military developments. Eventually, NATO as a military alliance became a political tool which has been used to implement western countries' policies towards the rest of the world after the end of the Cold War. Consequently, NATO's military missions have interfered in Russia's sphere of influence, which has encouraged a reshaping of Russia's relations with the western military alliance. NATO's actions challenged Russia to rethink its security strategy and modernize its military capabilities.

Russia's increasing military capabilities suggest that Russia will oppose future NATO expansion sand self-willed military missions. NATO interventions in Kosovo, Afghanistan and Libya have challenged Russian foreign and internal affairs. In the current multipolar world the relations of NATO and Russia could determine the balance of power in Europe, Caucasia, SouthCentral Asia and in parts of the Middle East. The struggle and resistance of Russia towards NATO leads to new debates, negotiations and conflicts which might highly influence regional and even global politics, economies and social affairs.

This research seeks to find out how different crises in Kosovo, Afghanistan and Libya were scripted by NATO and Russia. The hypothesis of this research claims that different NATO and Russian geopolitical discourses towards crises in Kosovo, Libya and Afghanistan have led to reciprocal accruing disagreements. With regard to the hypothesis, the aim of the research is to find out how NATO military interventions in Kosovo, Libya and Afghanistan have negatively affected relations with Russia. Ultimately, in order to achieve the aim of this study and prove its hypothesis, the critical geopolitical approach is chosen as a theoretical framework. 


\section{Theoretical Overview of the Critical Geopolitics}

The term 'geopolitics' has long been used to refer to the study of the geographical representations, rhetoric, and practices that underpin world politics. ${ }^{1}$ Nevertheless, with the end of the Cold War the world has changed dramatically and has led to the development of a more sophisticated geopolitics. In order to understand and actually analyze critical geopolitics, comprehension of classical geopolitics is required. Even though critical geopolitics is theoretically distinct from classical geopolitics, it is essential to understand and pay attention to the evolution of the geopolitical approach.

\subsection{The development of the geopolitical approach}

Geopolitics is a term coined by Rudolf Kjellen, who described geopolitics (geopolitik) as the problems and conditions within a state that arise from its geographic features. ${ }^{2}$ Throughout most of the twentieth century, geopolitics was limited to a geographical perception of the world in which the different political forces and states competed with each other. At the beginning of the twentieth century, Englishman H. J. Mackinder initially stood among the geopolitics thinkers with his exclusive approach to the world. In his work "The Geographical Pivot of History" (1904) he explained and defined world regions in detail and introduced the most meaningful of them: The World-Island and the Heartland (Appendix Nr. 1). ${ }^{3}$

Later on, the geopolitics pioneer's theory was developed and supplemented with new ideas by other thinkers. German K Haushofer in his writings presented ideas about different panregions; American N. J. Spykman analyzed the geopolitical concept of Rimland, which later on influenced the U.S. foreign policy during the Cold War; and S. B. Cohen treated the world's geopolitical structure as an evolving system composed of a hierarchy of levels-from the geostrategic realm through "the geopolitical region, national state and its sub-national units"

Inherently, engagement in geopolitics, from an academic perspective, was reserved for the powerful countries of the world. Thus, the opinion was created that 'real' geopolitics and geostrategy can only be carried out by the big states whose primary goal was to bolster their territorial positions, spread their influence and pursue territorial expansion. Later, expanding the

\footnotetext{
${ }^{1}$ John Agnew, Geopolitics: Re-visioning World Politics, Routledge; 2 edition (2003), 5

2 britannica.com, Encyclopedia Britannica: http://www.britannica.com/EBchecked/topic/319825/Rudolf-Kjellen (accessed Feb 2, 2014).

${ }^{3}$ H. J. Mackinder, "The Geographical Pivot of History", The Geographical Journal, Vol. 23, No. 4 (Apr., 1904), 421-437.

${ }^{4}$ S.B. Cohen, “Geopolitical realities and United States foreign policy”, Political Geography 22 (2003), 3.
} 
understanding of geopolitics among the major states, the geopolitical analysts and their ideas took on an increasingly important role in shaping geopolitical codes. In the twentieth century, the expansionist goals of Nazi Germany led to the Second World War, after which geopolitics as an academic discipline was seen in a negative light. The growing confrontation during the Cold War between the U.S. and Soviet Union encouraged the return of geopolitics as a tool in shaping foreign policy.

Nevertheless, there are other views explaining the development of geopolitics. John A. Agnew, a political geographer, distinguished the development of geopolitics in three periods: civilizational, naturalized and ideological. ${ }^{5}$ Although Agnew reviewed geopolitics from this distinct perspective, it was still argued that geopolitics ended with the end of the Cold War.

After the Cold War new geopolitical ideas started to turn up in academic discourse. The period after the end of the Cold War has seen a number of other dramatic changes that, along with the emergence of worldwide terrorist networks, might seem to challenge the continuing utility of geopolitical imagination as a singular guide to practice in world politics. ${ }^{6}$ This could also include the deepening cooperation of NATO countries, the enlargement of Alliance to the Balkans and east Europe; the menace of failed states, ethnic conflicts, spread of the radical Islamism, etc.

Changes in the international system challenged academics and think tanks to revise theories, including the geopolitical approach, and adopt them to the new order. The examples of the neo-Eurasianism and neo-Atlanticism illustrate how this has taken place. Although the end of the Cold War shaped the global order, certain scholars have still stayed with their modern geopolitical ideas and simultaneously opposed the critical approach in geopolitics.

For instance, neo-Eurasianism and neo-Atlanticism are attempts to revive classical geopolitics and explains the confrontation between the West and the rest. Both approaches, NeoEurasianism and Neo-Atlanticism are endeavors to espouse the importance of political geography and mapping. These and most other authors of "neo" approaches give themselves up to "neo games," carried away by the completely erroneous, mystically inflated idea of an eternal confrontation between the 'Ocean' or 'Atlantism' (in modern times- the United States and

\footnotetext{
${ }^{5}$ John Agnew, Geopolitics: Re-visioning World Politics, Routledge; 2 edition (2003), 86-113.

${ }^{6}$ Ibid, 1.
} 
Britain) and the 'Continent' or 'Eurasianism.' ${ }^{7}$ Neo-Eurasianism and Neo-Atlanticism became the coin of a few armchair scholars and publicists who nostalgically adopted modern geopolitics to the new international system after the Cold War.

Notwithstanding the "neo" approaches, in a table below the scholar of critical geopolitics, G. O. Tuathail, presents a contrasting vision of the new geopolitical appraoch and distinguishes it from modern geopolitics.

Table Nr. 1: Difference between Modern and Critical geopolitics

\begin{tabular}{|l|l|}
\hline Modern geopolitics & Critical geopolitcs \\
\hline Cartographic visualizations: maps & Telemetric visualizations: GIS \\
\hline East/West & Jihad, McWord \\
\hline Territorial power & Telemetric power \\
\hline Territorial enemies & Deterritorialized dangers \\
\hline National sovereignity & Globalization \\
\hline Hardware ascendant:GPR & Software ascendant: C4I2 \\
\hline Response to threats: slow and rigid & Flexible and rapid response \\
\hline
\end{tabular}

Source: G. O. Tuathail and S. Dalby, Rethinking Geopolitics. New York, Routledge (2002), 28.

\subsection{The critical geopolitical approach}

In the late 1980s, critical geopolitics appeared as a critique of modern geopolitics. However, the key critical geopolitical literature emerged only in the 1990s. The end of superpower rivalry, which had shaped the structure of (geo)political thought for over 40 years, further fueled interest in the spatiality of power in geography and throughout social science. ${ }^{10}$ The rethinking of power structure required critical thought that progressively was labelled as critical geopolitics.

According to Gearóid Ó. Tuathail and Simon Dalby, the main scholars of the critical geopolitics school, critical geopolitics "has emerged out of the work of a number of scholars in

\footnotetext{
${ }^{7}$ Valerii Senderov, "Neo-Eurasianism: Realities, Dangers, Prospects”, Russian Politics and Law, vol. 47, no. 1, (January-February 2009), 24

${ }^{8}$ GPR (Ground-penetrating radar); http://www.3d-radar.com/military/technology-2 (accessed Dec 2, 2013)

${ }^{9} \mathrm{C} 4 \mathrm{I} 2$ (Command, Control, Communications Computers, Information and Intelligence) http://www.globalsecurity.org/military/library/report/1989/CCE.htm (accessed Dec 2, 2013)

${ }^{10}$ Klaus Dodds, Merje Kuus and Joanne Sharp, The Ashgate Research Companion to Critical Geopolitics, Ashgate, (2013), 6
} 
the fields of geography and international relations who, over the two last decades, have sought to investigate geopolitics as a social, cultural and political practice."11 Critical geopolitics is not about 'the outside' of the state but about the very construction of boundaries of 'inside' and 'outside', 'here' and 'there,' the 'domestic' and the 'foreign'. ${ }^{12}$ For instance, the construction of Russian foreign policy also involves domestic policy, and it also reshapes political identity of indigenous and external actors. The same could be said about NATO; the fight against global terrorism affects member states and their political discourse.

Furthermore, "the main goal of the critical geopolitical approach is not just to characterize the geography of politics, but to analyze the actual politics of the geographical specification of politics." ${ }^{13}$ In other words, critical geopolitics does not only concentrate on the relations between states, but it also analyzes how particular relations and policies were created, approved and implemented.

John Agnew, another critical geopolitics theorist, claims that "critical geopolitics can be defined in a broad way as the critical sense that world politics is underpinned by assumptions and schemas about the ways in which geographical divisions of the world, strategic plans, and global images enter into the making foreign policy". ${ }^{14}$ One can presuppose that premises and schemas are socially constructed by particular people who were influenced by identity, history, geographical position, etc.

Other academics argue that the basic concept behind critical geopolitics is that intellectuals of statecraft construct ideas about places; these ideas have influence and reinforce their political behaviors and policy choices. ${ }^{15}$ However, the discourse of geopolitics does not belong to exclusively political elites anymore. Critical geopolitics broadens the analysis of geopolitics from state actors located in formal institutions (such as government ministries, universities or think tanks) to non-state actors. ${ }^{16}$ For instance, Russian president Vladimir Putin does not create his own doctrines and strategies, his ideas are influenced and shaped by political advisers, policy makers and even by civil society groups, insurgencies, NGOs, etc.

\footnotetext{
${ }^{11}$ Gearóid Ó Tuathail and Simon Dalby, Introduction: Rethinking Geopolitics, Routledge; second edition, (2002) 2

${ }^{12}$ Ibid, 4.

${ }^{13}$ Klaus Dodds, Merje Kuus and Joanne Sharp, 6.

${ }^{14}$ Klaus Dodds, Merje Kuus and Joanne Sharp, “The Ashgate Research Companion to Critical Geopolitics', in The Origins of Critical Geopolitics, ed. John Agnew, Ashgate, (2013), 19-20.

${ }^{15}$ Fouberg, Erin H., Alexander B. Murphy, and H. J. de Blij, Human Geography: People, Place, and Culture (10 ed.), (2012), 535.

${ }^{16}$ Klaus Dodds, Merje Kuus and Joanne Sharp, 7.
} 
Consequently, discourses are seen to influence the rules and conventions by which political behavior is structured, regulated and judged. ${ }^{17}$ The scholars of the critical geopolitics school claim that geopolitics must be conceptualized as a form of political practice and a discourse. However, many writers limit the critical geopolitical approach with particular phrases and ideas. Gearóid Ó. Tuathail and Simon Dalby are among the few scholars who have fully conceptualized and theorized the critical geopolitical approach. Their input to critical geopolitics is significant. They distinguish five fundamental arguments of critical geopolitics:

1. Geopolitics is a much wider cultural phenomenon than is normally defined and comprehended by the geopolitical tradition of wise men's statecraft.

2. Critical geopolitics bears witness to the irredeemable plurality of space and the multiplicity of possible political constructions of space. Thus, it pays particular attention to the boundary-drawing practices and performances that characterize the everyday life of states.

3. Critical geopolitics argues that geopolitics is not a singularity but a plurality. Critical geopolitics must be considered as a political activity carried out by a range of political actors and not limited to a small group.

4. Critical geopolitics argues that the practice of studying geopolitics can never be politically neutral. It is always influenced by certain values, experiences, etc.

5. Ultimately, in conceptualizing geopolitics as 'situated reasoning' a critical perspective also seeks to theorize its broader socio-spatial and techno territorial circumstances of development and use. Historically, the question of geopolitics has always been the question of states and their societies, technological networks and their relationship to territoriality. ${ }^{18}$

The five arguments above conceptualize the critical geopolitical approach in terms of the meaning, space and stability. However, critical geopolitics argue that these three elements are influenced and shaped by other factors, such as certain values, identity, history, state apparatus, etc. ${ }^{19}$ Consequently, knowledge of these features is fundamental to the successful operationalization of the state's/agency's "real geopolitics." At this point "real geopolitics" must be understood as criticism to classical geopolitics, which, according to critical geopolitics, is

\footnotetext{
${ }^{17}$ Klaus Dodds, Global Geopolitics: A Critical Introduction, Routledge (2004), 31.

${ }^{18}$ Gearóid Ó Tuathail and Simon Dalby, Rethinking Geopolitics, Routledge; second edition (2002) 3-6.

${ }^{19}$ Ibid, 6.
} 
outlived and cannot explain contemporary events. However, this research does not seek to find out "the real geopolitics" of NATO or Russia. The sub-chapter below will concentrate on the particular critical geopolitical aspects that might help to reveal NATO and Russian geopolitical discourses towards crises in Kosovo, Libya and Afghanistan.

\subsection{The method of research}

Gearóid Ó. Tuathail provides a schematic critical geopolitics conceptualization which is also used as the methodology for this research. The table below presents its key features.

Table Nr. 2 Geopolitics: A Critical Geopolitics Conzeptualization.

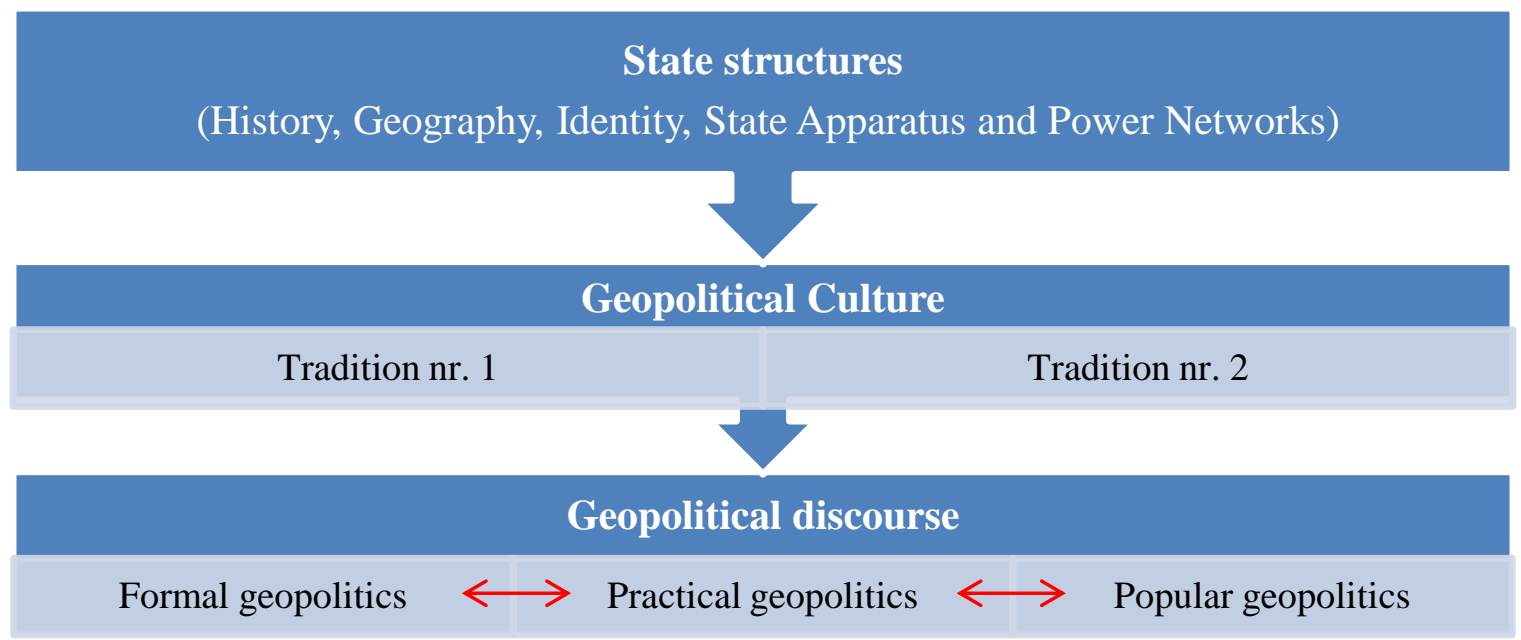

Source: G. O. Tuathail, S. Dalby and P. Routledge, The Geopolitics Reader, Routledge, second edition (2006), 8

Gearóid Ó. Tuathail argues that all states, as recognized territorial units within an international system of states, have a geopolitical culture. ${ }^{20}$ Geopolitical culture is mostly understood as a state/agency's unique identity, position and influence in world politics. In other words, it could be also defined as geopolitical tradition which is one of the approaches to the geopolitical culture. States or agencies do not limit themselves only with one geopolitical tradition. Depending on certain characteristics of the state or agency there might be even more than one geopolitical tradition. In addition, Gearóid Ó. Tuathail asserts that geopolitical culture or tradition is conditioned by a series of factors:

- A state's geographical situation;

- Historical formation and bureaucratic organization;

${ }^{20}$ G. O. Tuathail, S. Dalby and P. Routledge, The Geopolitics Reader, Routledge; second edition (2006), 7. 
- Discourses of national identity;

- Traditions of theorizing a state's relationship to the wider world;

- The networks of power that operate within the state. ${ }^{21}$

Gearóid Ó. Tuathail's distinction once again demonstrates that the geopolitics is more than a political geography and mapping. On the one hand, it is a broad and even complicated structure of certain elements, but on the other hand, it helps better to understand the actions taken by the particular state or agency in the international order.

For instance, there might be three different geopolitical traditions in the Russian Federation: 'Russia within Europe', 'Eurasian theory', and 'Russia as a bridge between East and West'. ${ }^{22}$ Every tradition was influenced by particular historical factors, such as Slavophilism, or by Western models and institutions, or by particular technological and economic developments. In addition, the Russian geopolitical tradition in Europe has been influenced by European states and NATO. The Alliance's actions invoked a particular Russian response and counter-reaction which have led to reciprocal accruing disagreements and cooperation. Regarding NATO's past historical events and new global severities, geopolitical traditions could be distinguished as 'Euro-Atlantic collective defence' and 'crisis manager'. It is possible to argue that NATO could be considered as a hybrid, a collective security club and an agency for conflict prevention. One the one hand, NATO concentrates on the security of Euro-Atlantic space, and on the other hand it seeks to expand its capabilities and participate in various operations and missions all around the globe. However, as the research suggests later, NATO's geopolitical tradition of “crisis manager" was partly unsuccessful due to particular reasons.

Furthermore, geopolitical tradition finds concrete expression in the form of particular geopolitical discourses. Discourses are not merely speech or written statements but actually the rules by which verbal speech and written declarations are made meaningful. ${ }^{23}$ Moreover, in the critical geopolitics approach discourses are not only produced by political elites, but also throughout state-centered society at multiple sites. ${ }^{24}$ Above, in Table Nr. 2 (see page 15), Gearóid Ó. Tuathail distinguishes critical geopolitics discourse into "formal geopolitics", "practical geopolitics", and "popular geopolitics".

${ }^{21}$ Ibid, 7.

${ }^{22}$ G. O. Tuathail, S. Dalby and P. Routledge, The Geopolitics Reader, Routledge; second edition (2006), 8

${ }^{23}$ Gearóid Ó Tuathail and Simon Dalby, "Geopolitics and discourse: Practical geopolitical reasoning in American foreign policy”, Political Geography Vol. 11, No. 2, March 1992, 95.

${ }^{24}$ G. O. Tuathail, S. Dalby and P. Routledge, 9. 
"Formal geopolitics" refers to the experts or the strategic community of the state who create political doctrines, strategic studies or specific bureaucratic reports. For instance, NATO's Supreme Headquarters Allied Powers Europe (SHAPE) and Allied Command Transformation (ACT) are the key institutions that promote changes by driving, facilitating, and advocating continuous improvement of Alliance capabilities to maintain and enhance the military relevance and effectiveness of the Alliance. ${ }^{25}$ In Russia, the Ministry of Defence and the Security Council are the leading institutions that ensure the establishment of particular strategies, doctrines, etc. Undoubtedly, under all these institutions there are many committees, working groups, think tanks, and bureaucrats who are responsible for the efficient creation and implementation of strategies.

Sometimes "formal geopolitics" and "practical geopolitics" reproduce each other, particularly when politicians are directly involved in the strategy-making. On the other hand, "practical geopolitics" is mostly related with the leaders of the state and foreign affairs policy makers. ${ }^{26}$ "Practical geopolitics" represents the actual practice of policy that is usually expressed by official political speeches or the state/agency's actions. In NATO, practical geopolitics is mostly related with the North Atlantic Council (NAC) where political decisions are adopted by permanent member states delegations. In comparison with Russia, NATO's "practical geopolitics" requires a consensus among all representatives of member states. Consequently, NATO's political decisions and actions ("practical geopolitics") represent a unilateral position of the entire Alliance. In theory, Russian "practical geopolitics" applies to already mentioned the Security Council, current president Vladimir Putin, prime minister Dmitry Medvedev, the Minister of Foreign Affairs Sergey Lavrov, and other important politicians. However, in reality, Russian "practical geopolitics" belongs to a small circle of the decision makers, and more narrowly just to Putin.

Last but not least, "popular geopolitics" refers to the mass media, state rituals and public opinion. Taking into account that NATO is an agency/international actor that unites a group of states, thus both Russia and NATO use mass media for core dissemination of ideas and propaganda to societies. Similar to mass media, state rituals also shape and transform the opinion of people. For instance, NATO is presented by certain media as the exclusive club of democratic

\footnotetext{
${ }^{25}$ NATO Allied Command Transformation (ACT) http://www.act.nato.int/mission (accessed Feb 25, 2014.)

${ }^{26}$ Gearóid Ó Tuathail and Simon Dalby, Rethinking Geopolitics, Routledge; second edition, (2002), 12.
} 
countries that protects human rights, international law and Russia represented by its media as the counter-balance to the hegemony of the west (NATO).

What is more, Gearóid Ó. Tuathail argues that "not all geopolitical discourses are created or treated equally." 27 On the one hand, some geopolitical discourses are produced by military or states institutions, military specialists and universities. On the other hand, one of the discourses could be also influenced by civil society: NGO's, think tanks, etc. Moreover, journals and newspapers often promote certain geopolitical discourse that only serves a political agenda. ${ }^{28}$

Eventually, all three geopolitical discourses interact and influence each other, thus the lines between them could blur. Formal, practical, and popular geopolitics are the outcome of the dominant geopolitical cultures and traditions. In comparison with Russia as a state actor, NATO is considered a military alliance. However, this research seeks to analyze NATO from a different perspective and perception. NATO member states represent a certain western culture and traditions, which eventually unite them to the unprecedented agency in the international order. Undoubtedly, NATO as an international institution/agency depends on its member states and their political decisions. On the other hand, member states also depend on political and military decisions within NATO (for instance, NATO's article V). This research will analyze NATO as an international actor, which has its political decision and strategy makers. The western media, as the representative of the "popular geopolitics" will be taken into consideration as the "fourth government of NATO”, which monitors, criticizes and even spreads propaganda about NATO's activities.

A critical geopolitical approach helps to look at world affairs critically. It provides a framework within which indigenous events in one place could be linked to global politics. In addition, analyses of the geopolitical discourses could provide an opportunity to predict the future direction of regional or world politics.

Ultimately, this research will mostly pay attention to three essential parts of the critical geopolitics: "Formal geopolitics" (analyses of think tanks, specialists, etc.), "practical geopolitics" (the decisions of policy makers, official statements, documents, strategies and speeches) and "popular geopolitics" (the discourse of the media and surveys). The combination of these three elements will allow us to determine certain NATO and Russian geopolitical

\footnotetext{
${ }^{27}$ G. O. Tuathail, S. Dalby and P. Routledge, The Geopolitics Reader, Routledge; second edition (2006), 9.

${ }^{28}$ Ibid, 9.
} 
discourses towards crises in Kosovo, Libya and Afghanistan. With regard to evidences of crises, NATO and Russian geopolitical discourses will be evaluated from very positive, positive, neutral, to negative and very negative. It will provide an opportunity to see how both sides have scripted these crises and how in the long term NATO's military interventions in Kosovo, Libya and Afghanistan have influenced relations with Russia and how this in turn has affected the international order. 


\section{Methodology}

This research is different from other similar works with its exclusive approach to NATO and Russian relations as they were affected by NATO military interventions in Kosovo, Libya and Afghanistan. This research reviews more than a decade which actually allows a better look at military operations from a distance. Critical geopolitics theory seeks to investigate geopolitics as a cultural, social and political practice. Critical geopolitics helps to review not only what is "outside" of actor/state, but what is 'inside', the 'domestic' and the 'foreign', the 'here' and 'there'. ${ }^{29}$ Analysis of three different cases gives an opportunity to anticipate and indicate how NATO and Russia have scripted these crises and how their different geopolitical discourses towards crises have led to reciprocal accruing disagreements or cooperation.

With regard to the already mentioned hypothesis and aim of this research three goals are introduced. First of all, the author seeks to conceptualize the critical geopolitical theory and relate NATO and Russian positions to it. Secondly, to compare and contrast Russian and NATO's geopolitical discourses towards the Kosovo, Libyan and Afghanistan crises and clarify the consequences for their mutual relations and cooperation in the international arena. Finally, to encapsulate all insights and draw conclusions.

Additionally, using the critical geopolitical approach this research seeks to answer several research questions:

- What are NATO and Russian geopolitical discourses towards the crises in Kosovo, Libya and Afghanistan?

- How have the NATO military interventions affected relations with Russia after the Cold War?

In order to satisfy and implement my research goals, descriptive method, discourse analysis and a comparative approach will be applied. The descriptive method will be used in order to present case studies of crises in Kosovo, Libya and Afghanistan. The author briefly reviews the development of crises and reasons why NATO intervened in these three countries. Moreover, discourse analysis and a comparative approach will be used to scrutinize Russian and NATO's geopolitical discourses towards crises in Kosovo, Libya and Afghanistan after the end of the Cold War. These methods, especially the comparative method, provide an opportunity for

\footnotetext{
${ }^{29}$ G. O. Tuathail, S. Dalby and P. Routledge, The Geopolitics Reader, Routledge; second edition (2006), 8.
} 
a closer examination of the different perceptions of NATO and Russia. In this research the (official) discourse analysis is mostly used to compare and contrast different NATO and Russian official documents, treaties, agreements, speeches and the media reports. Consequently, it allows for a better look at different NATO and Russian perceptions towards crises. The discourse analysis leads to the comparative method (broadly used in the section 5.The Interaction of Geopolitical Discourses), which helps to investigate changes in NATO and Russian geopolitical discourses during times of crisis. This method eventually provides an opportunity to perceive and indicate facts where, when and, especially, how NATO's military interventions in Kosovo, Libya and Afghanistan influenced relations with Russia.

Furthermore, in the theoretical part, fundamental ideas of critical geopolitics will be reviewed and conceptualized. The books listed were used as the main sources of the critical geopolitics: Gearóid Ó Tuathail and Simon Dalby, Introduction: Rethinking Geopolitics, Routledge; second edition, (2002), G. O. Tuathail, S. Dalby and P. Routledge, The Geopolitics Reader, Routledge, second edition (2006), John Agnew, Geopolitics: Re-visioning World Politics, Routledge; 2nd edition, (2003) and Klaus Dodds, Merje Kuus and Joanne Sharp, The Ashgate Research Companion to Critical Geopolitics, Ashgate (2013). Simon Dalby and especially Gearóid Ó Tuathail are the main theorists of critical geopolitics that are used in this research. Interpretations and additional ideas regarding Gearóid Ó Tuathail's perception about critical geopolitics are reviewed in other writings, which are already mentioned above. Undoubtedly, there are other authors, such as Erin H. Fouberg, Alexander B. Murphy, H. J. de Blij, John Agnew and Klaus Dodds, who study critical geopolitics; however, their writings pale in comparison to the volume and precise conceptualization of the critical geopolitics written by Gearóid Ó Tuathail and Simon Dalby.

In the empirical part, with regard to "formal geopolitics," different books, articles and journals will be used in order to indicate the specific features of NATO's and Russia's formal geopolitics. In the section about the Kosovo crisis, Albrecht Shnabel and Ramesh Thakur, Kosovo and the challenge of humanitarian intervention: selective indignation, collective action, and international citizenship, United Nations University Press, (2000); John Norris, Collision course: NATO, Russia, and Kosovo, Praeger Press, (2005); Дмитрий Тренин and Екатерина Степанова, Косово: международнье аспекты кризиса, Moscow Carnegie Center, (1999) and 
Tim Judah, Kosovo: what everyone needs to know, Oxford University Press, USA (2008) are used.

In the section about the Afghanistan crisis the research has relied mainly on M. J. Williams, The Good War: NATO and the liberal conscience in Afghanistan, Palgrave Macmillan, (2011); Oksana Antonenko, "The Central Asian states and Russia", in Afghanistan to 2015 and beyond, ed. Toby Dodge and Nicholas Redman, Routledge, (2011) and Sten Rynning, NATO in Afghanistan: The Liberal Disconnect, Stanford Security Studies (2012) and various journal articles.

Furthermore, Alison Pargeter, Libya: The Rise and Fall of Qaddafi, Yale University Press, (2012); Campbell Horace, Global NATO and the Catastrophic Failure in Libya, Monthly Review Press, (2013); Geir Ulfstein And Hege Føsund Christiansen, "The Legality Of The NATO Bombing In Libya", ICLQ vol. 62, (2013) and other books and articles are used to analyze the Libyan crisis.

Analyses and reviews of these writings make it possible to understand better the "formal geopolitics" (think tanks, specialists, etc.) of NATO and Russia. Using already discussed methods, all facts and information will be compared and contrasted to each other.

Furthermore, in order to identify Russian and NATO's "practical geopolitics." the decisions of policy makers, official statements, documents, strategies and speeches are compared and contrasted to each other. Legal documents such as NATO strategic concepts, Russian foreign and military strategies, UN Security Council resolutions, the Prague Summit declaration of NATO (2002) and similar reports are used. Moreover, official speeches of Russian and NATO political leaders are taken from Ministry of the Foreign Affairs of the Russian Federation and NATO official website.

Last but not least, "popular geopolitics" of NATO and Russia are scrutinized and compared regarding the discourse of the media and surveys. Major Western and Russian media as well as social media will be reviewed and compared. Regarding the circulation and popularity of the media, the news coverage from BBC, CNN, Der Spiegel, Reuters, The New York Times, Izvestia, Kommersant, Lenta and Pravda are analyzed. Moreover, several surveys such as Financial Times/Harris March-April 2011 and The German Marshall Fund of the United States, "Transatlantic Trends survey 2013" about public opinion towards the crises are used in order to 
supplement and justify arguments. The timeframe of the media and surveys monitored is from 1999 to March 2014.

Additionally, NATO and Russian "formal geopolitics", "practical geopolitics" and "popular geopolitics" are compared and contrasted to each other. All collected data and information are scrutinized and compared with other opinions, academic discourses, books and journals. Regarding the case studies for this research, different sources are used. Martin A. Smith, "NATO-Russia relations: will the future resemble the past?", in NATO in search of a vision, ed. Gulner Aybet and Rebecca R Moore, Georgetown University Press, (2010); Oksana Antonenko, "The Central Asian states and Russia", in Afghanistan to 2015 and beyond, ed. Toby Dodge and Nicholas Redman, Routledge, (2011); Eugeniusz Smolar, "Transatlantic relations and NATO”, European View 10:127-135, Centre for European Studies (2011); Andreas Behnke, NATO's Security Discourse after the Cold War: Representing the West, Routledge; 1st edition, (2012), and other books and articles have been employed which discuss NATO-Russian relations after the Cold War.

Furthermore, the qualitative research approach has been used in order to interview officials, authorities and scholars. However, a structured interview method is not a fundamental part of this methodology, it is only used to get additional information and receive experts' opinions which are not available in the literature. The interviewees were selected regarding research problems. The author of this research sought to receive reliable interviews from people who are aware of NATO and Russian geopolitical discourses. Even though there were ten requests sent to the interviewees, only four of them were successful. Some of them could not attend an interview due to technical issues, the rest simply provided valuable sources which helped in this research. Nevertheless, the author believes that interviews conducted via Skype or during live meetings are still beneficial. The composition of the interviewees is as follows:

1. The Senior Counselor Denis Gonchar from the Russian Embassy in Washington D.C. (interview was conducted on February 13, 2014).

2. Dr. Ieva Karpaviciute, a special Lithuanian attaché to NATO HQ (interview was conducted via Skype on February 28, 2014).

3. The senior expert Vadim Volovoj from the Centre of Geopolitical Studies (interview was conducted via Skype on March 2, 2014). 
4. Professor Boris Barkanov, a lecturer in Political Science at West Virginia University (interview conducted on March 5, 2014).

During interviews the main goal was to question and find out:

- How NATO military interventions in Kosovo, Libya and Afghanistan influenced relations with Russia.

- How Russia scripted these crises in the Post Cold War era.

- How did these events shape Russia's perception of the international order. 


\section{Case Studies in Times of Crisis}

During the post-Cold War era NATO emerged as an active crisis manger all around the globe. In the last two decades NATO has been participating in various missions and operations: Humanitarian support after the hurricane Katrina in the US and earthquake in Pakistan; peacekeeping missions in Bosnia and Herzegovina as well as the former Yugoslav Republic of Macedonia; Counter-piracy in the Gulf of Aden and off the Horn of Africa; monitoring the Mediterranean Sea; supporting the African Union (AU) in its peacekeeping missions on the African continent; and ultimately, the military campaigns in Kosovo, Afghanistan and Libya.

The last three military operations appear as the most fundamental ones due to the significant number of participating NATO member states and partners, the use of resources and the duration of the operations. Besides, NATO military interventions in Kosovo, Libya and Afghanistan influenced regional politics, economies and relations with strategic partners, including Russia. Consequently, these case studies will concentrate only on the analyses of three NATO military operations outside its boundaries and contrast their impacts on relations with Russia. Due to the long research timeframe, the crises in Kosovo and Afghanistan are divided into two parts - the beginning of the conflicts and their final stages. The sub-chapters below provide brief descriptions of the crises and reasons for the NATO military operations.

\subsection{Kosovo}

Since the beginning of the twentieth century, Kosovo has been one of the most explosive conflict zones on the European continent. ${ }^{30}$ With the decline of the Ottoman Empire at the beginning of the twentieth century, the Balkan states became the geopolitical zone where the western powers and Russia were constantly in rivalry with each other and trying to strengthen their influence. Moreover, disputes among Albanians and Serbs stretch back centuries. In 1974 under the Yugoslavian constitution, Kosovo gained autonomy within the Serbian republic. Nevertheless, the relations between Serbs and Albanians in Kosovo continued to erode with the rise of Slobodan Milosevic on the Yugoslav political scene. ${ }^{31}$ In 1991 the disintegration of Yugoslavia enhanced the tension between different parties. These pressures also took on religious dimensions, as the Serbs were Orthodox Christians and Kosovar Albanians were

\footnotetext{
30 Albrecht Shnabel and Ramesh Thakur, Kosovo and the challenge of humanitarian intervention: selective indignation, collective action, and international citizenship, United Nations University Press (2000), 19

${ }^{31}$ John Norris, Collision course: NATO, Russia, and Kosovo, Praeger Press (2005), xx
} 
Muslims. ${ }^{32}$ The fundamental problem of the conflict was the divergent views of Serbs and Albanians over the legal status of Kosovo.

During the disintegration of Yugoslavia in the 1990s the Serbian police and the Kosovo Liberation Army (KLA) became radicalized and constantly escalated the conflict in Kosovo region. With the increase of casualties, the international community decided to get seriously involved to search for a diplomatic solution. Neither the threat of NATO air strikes in the fall of 1998, nor the peace negotiations at Rambouillet in February 1999 helped to resolve the political gridlock. In the beginning of 1999 renewed clashes between Serbian forces and the KLA justified the decision to deploy NATO forces in a military campaign called Operation Allied Force (OAF).

Almost a decade later, on February 17, 2008 Kosovo declared its unilateral independence from Serbia. From the first days it became a controversial topic in the international community. On the one hand, from a Russian perspective the independence of Kosovo is "an example of imperial thinking, a manifestation of the policy of diktat and arbitrariness in international affairs." 33 The independence of Kosovo was supported only by pro-western countries. On the other hand, western supporters of Kosovo claim that its independence is 'sui generis', a unique case with its own special characteristics. Consequently, different geopolitical discourses turned out between NATO member states and Russia.

\subsection{Afghanistan}

The first disputes over Afghanistan between western powers and Russia appeared in the nineteenth century, when the expansion of tsarist Russia to Central Asia threatened the British Empire and its possessions in south Asia. Eventually, the crisis was solved by 1864 memorandum, in which both sides agreed that Russia's advancement into Central Asia would be limited and would not interfere with Afghanistan. Later on, in 1919 there were initial attempts to establish the first centralized state of Afghanistan. The early state formation in Afghanistan was plagued by constant tensions between various indigenous tribal groups of Afghans. ${ }^{34}$ During the Cold War period, Afghanistan became a battle arena for a proxy war between the U.S. and the USSR. The Soviets fought a decade-long war in Afghanistan, however, due to the American

\footnotetext{
${ }^{32}$ Ibid, xix

${ }^{33}$ Vladimir Kozin, Five lessons from Kosovo's “independence”, International Affairs (Moscow) 54: 4, 2008, $125-128$.

${ }^{34}$ M. J. Williams, The Good War: NATO and the liberal conscience in Afghanistan, Palgrave Macmillan (2011), 12
} 
military help to Afghanis, the Soviet Union failed to achieve a victory. In 1989 with the withdrawal of the Soviet military, internal problems in Afghanistan did not end. At the beginning of the post-Cold war era, due to the U.S. and international community concentration on the other crises (Iraq, Somalia, tension between Pakistan and India, etc.) and not enough attention on Afghanistan, armed insurgent groups overtook control of the civilian government. Eventually, in the period of 1996-2001 a majority of the Afghanistan's territory was controlled by the Taliban. Its controversial leaders emerged as an international threat when they joined the call for a global jihad against the U.S. and its allies and participated in acts of terror by providing safe have for al Qaeda.

On September 11, 2001 al Qaeda hijacked several planes, which were successfully used as the weapon against U.S. civilians and infrastructure. Consequently, for the first time in history, NATO's Article V was invoked to respond to the new menace - terrorism. Afghanistan was recognized as the first potential target because it had hosted insurgent terrorist groups. Consequently NATO was ready to act for the first time outside the European continent.

Thirteen years has already passed since the first invasion to Afghanistan in 2001. According to the current agreements, by the end of the year 2014 NATO's troops are set to withdraw from Afghanistan's territory. The question of the victory against endless terrorism is dubious. Accoriding to Stephen M. Walt, a professor from Harvard university, NATO's legacy in Afghanistan was just one failed endeavor after another." ${ }^{635}$ Until 2005 NATO successfully restored order in Kabul and its surroundings, and discredited the Taliban's leadership. However, later on the Alliance entered political and strategic gridloack, and lack of future vision raised a rethorical guestion - what to do next? The outcome of the current condition of Afghanistan is the consequence of NATO's strategy of the last 7-9 years. NATO and the U.S. failed in terms of stratigical thinking and planning. Afghanistan's development according the western model failed. The United States waged a controversial war in Iraq and redeployed the majority of intelligence and military capacities from Afghatanistan. The annual casualties of NATO

\footnotetext{
${ }^{35}$ Stephen M. Walt, "The Top 10 Mistakes Made in the Afghan War", Foreign Policy, February 3, 2014; Source: http://www.foreignpolicy.com/articles/2014/02/03/the top ten mistakes made in the afghan_war (accessed March 14, 2014);
} 
dramatically increased (see Appendix Nr. 7) and the Alliance lost public support due to the extented military operation, waste of resources and money, and uncertainty of final victory. ${ }^{36}$

\subsection{Libya}

Postcolonialism brought changes all around the world, including the territory of Libya. In 1951 the withdrawal of the Italians propelled the Libyan national ambitions which were actively supported by western countries, particularly by the U.S. and the U.K. The same year the newly installed King Idris Al-Sanussis proclaimed Libya's independence and ultimately the unification of three regions (Tripolitania, Fezzan and Cyrenaica) was achieved for the first time in Libyan history. The pro-western monarchy had close ties with the U.S. and the United Kingdom which eventually, due to the rivalry with the Soviets, established military bases on the territory of Libya. Consequently, the foreign military bases provoked anger among the local population and stirred Arab nationalism. ${ }^{37}$ In the 1960s Muammar Gaddafi appeared as the vital leader of the nationalists who were seeking changes in the ruling elite. Paradoxically, Gaddafi was an officer who was trained at a military academy under British supervision. With the changes in foreign policy and the withdrawal of its troops overseas, Britain could no longer offer strong military assistance to the Libyan monarchy and eventually in 1969, Libya fell under the control of the new leader, Muammar Gaddafi, with minimal bloodshed.

By the end of 2010, the world was shocked by the spreading unrest and protests all around North Africa and the Middle East. Libyan groups, following the progress in Tunisia and Egypt, made their own demands and launched demonstrations against the government. Nevertheless, the Gaddafi regime used force and dispersed the crowds which suffered injuries and casualties. The clashes between government forces and protestors intensified and ultimately led to open armed conflict in a civil war.

Regional organizations saw the need for stronger international pressure and by early March 2011 the Gulf Cooperation Council and the Organization of Islamic Conference endorsed a no-fly zone. ${ }^{38}$ Consequently, on March 17, 2011 with ten votes in favor, none against and five abstentions (Germany and the four BRIC countries: Brazil, Russia, India and China), the UN SC

\footnotetext{
${ }^{36}$ Ivan Dinev Ivanov, Transforming NATO: New Allies, Missions and Capabilities, Rowman \& Littlefield Publishers, (2011), 217

${ }^{37}$ Alison Pargeter, Libya: The Rise and Fall of Qaddafi, Yale University Press (2012), 44

${ }^{38}$ Geir Ulfstein And Hege Føsund Christiansen, "The Legality Of The NATO Bombing In Libya", ICLQ vol. 62, (2013), 160.
} 
resolution 1973 was adopted. NATO and its partners were ready to act and implement all measures of the resolution $1973 .^{39}$

In the following chapter all three cases will be scrutinized and analyzed regarding NATO and Russian geopolitical discourses in relation to them. Then all observations will be compared and integrated with each other. Eventually, the chapter will provide evidence of similar or different NATO and Russian geopolitical discourses that led to reciprocal accruing disagreements or cooperation.

${ }^{39}$ UN SC resolution Doc S/RES/1973 (March 17, 2011); Source:

https://www.un.org/News/Press/docs/2011/sc10200.doc.htm (accessed March 21, 2014). 


\section{Geopolitical Discourses during Crises}

\subsection{NATO's geopolitical discourses}

The next three sub-chapters will concentrate on analyses of NATO's geopolitical discourses in Kosovo, Libya and Afghanistan. "Formal geopolitics" (analyses of think tanks, specialists, etc.), "practical geopolitics" (the decisions of policy makers, official statements, documents, strategies and speeches) and "popular geopolitics" (the discourse of the media and surveys) will be scrutinized and determined.

\subsubsection{The Kosovo crisis}

In 1999, in starting NATO military campaign Operation Allied Force (OAF), the allies were united by a shared understanding that NATO was acting in the conformity with its liberal democratic values. ${ }^{40}$ The massacres in Srebrenica in 1995 in Bosnia were a seminal event and important in changing the course of history in Kosovo. One of the main reasons given by Western leaders for the intervention was to prevent a humanitarian catastrophe as had occurred in Bosnia. ${ }^{41}$ In addition, NATO believed that military intervention, or in other words, air strikes would lead to negotiations with Milosevic. However, Milosevic was hoping for support from the Russian Federation, thus he eventually rejected any negotiations with NATO.

From the early stages of the OAF, NATO declared its official and well-organized "practical and formal geopolitical," position towards the Kosovo crisis:

- NATO's strategy is to halt the atrocities and support the completion of negotiations on an interim political settlement for Kosovo;

- NATO is ready to take whatever measures are necessary;

- The Council has therefore agreed today that the NATO Secretary General may authorize air strikes against targets on Former Republic of Yugoslavia (FRY) territory. ${ }^{42}$

Even though NATO sought a non-violent solution since the beginning of the Kosovo crisis, the Alliance member states were ready to implement hard power if the negotiations between Serbia and Albanians in Kosovo would have failed. NATO's "formal and practical

\footnotetext{
${ }^{40}$ Alexandra Gheziu, NATO in the "New Europe": The Politics of International Socialization after the Cold War, Stanford University Press (2005), 239.

${ }_{41}^{41}$ Judah Tim, Kosovo: what everyone needs to know, Oxford University Press, USA (2008), 89.

42 Statement by the North Atlantic Council on Kosovo, January 30, 1999, http://www.nato.int/cps/en/natolive/official_texts_27459.htm?selectedLocale=en (accessed March 2, 2014).
} 
geopolitical" position was strengthened by certain elements. First of all, success in the 1995 Bosnia crisis enhanced NATO's self-confidence as a crisis manager outside the Alliance boundaries. And secondly, the controversial Clinton doctrine authorized the use of bombing. ${ }^{43}$ According to the Clinton doctrine, the US and NATO forces could go into battle for the principle of morality, human rights, etc. It was criticized by Russia as a selective policy because when NATO forces bombed Serbia, the Rwanda and Sudan crises were left in the political background.

Nevertheless, on March 23, 1999, the day before the air strikes, NATO issued its official and bizarre statement: "NATO's overall political objectives remain to help achieve a peaceful solution to the crisis in Kosovo by contributing to the response of the international community. Alliance military action is intended to support its political aims."44

Controversially, NATO had launched a military operation in order to achieve peace and stability by force. As the result, FRY blamed NATO for its illegal aggression against a sovereign state. The UN found itself sidelined by NATO: "Security Council sanction for the bombing was neither sought nor given," according to a UN publication. ${ }^{45}$ On one side of the coin, NATO violated international law and without UNSC authorization launched the bombing campaign against Serbia, but on the other side, NATO appeared as an united and a well-organized western alliance which took on the responsibility to stabilize the south-eastern part of Europe. Ultimately, the air strikes could also be understood as the point at which NATO "redeemed its credibility" after a few years of inactivity following the resolution of the conflict in Bosnia. ${ }^{46}$

Furthermore, NATO's "formal and practical geopolitics" was also promoted by the Western media, which represents NATO's "popular geopolitics" in this study. From the outset of the bombing the media wrote daily about the progress of the military campaign against Serbia. Dr. Steven Livingston, an analyst of communication and media, estimated that in a two and a half month period (March 23 - June 10, 1999) CNN wrote 2600 stories about Kosovo. ${ }^{47}$ At the

\footnotetext{
43 Charles Krauthammer, "The Clinton doctrine", $\quad$ CNN, March $29, \quad 1999$ http://www.cnn.com/ALLPOLITICS/time/1999/03/29/doctrine.html (accessed March 2,2014).

44 Political and Military Objectives of NATO Action with regard to the crisis in Kosovo, March 23, 1999: http://www.nato.int/cps/en/natolive/official_texts_27451.htm?selectedLocale=en (accessed March 2, 2014).

45 Albrecht Shnabel and Ramesh Thakur, Kosovo and the challenge of humanitarian intervention: selective indignation, collective action, and international citizenship, United Nations University Press (2000), 5.

${ }^{46}$ David S. Yost, NATO Transformed: The Alliance's New Roles in International Security, United States Institute of Peace Press, (1998), 195.

47 Steven Livingston, "Media coverage of the war: an empirical assessment", in Kosovo and the challenge of humanitarian intervention: selective indignation, collective action, and international citizenship, ed. Albrecht Shnabel and Ramesh Thakur, United Nations University Press (2000), 360.
} 
same time a comparable situation could also be noticed in BBC and in Der Spiegel. In two and a half months the Kosovo crisis was covered 1795 and 1012 times respectively. The huge interest of the media has been referred to as the "the CNN effect", which impacted policy developments regarding the Kosovo crisis. Furthermore, the global media agencies also affected the agendasetting, or in other terms - the "practical geopolitics" of NATO. Emotional reactions towards atrocities and the humanitarian crisis in Kosovo influenced the priorities of NATO. After a few weeks of air strikes, the media informed the public about the flow of refugees from Kosovo. ${ }^{48}$ Until the media reports, the Alliance only concentrated on the outcome of the air strikes. Consequently, NATO's perception of the Kosovo crisis switched from the air strikes campaign to the deployment of Kosovo Peacekeeping Force (KFOR) and humanitarian aid. ${ }^{49}$ During the crisis "practical geopolitics" appeared as an important factor that shaping the overall NATO's geopolitical discourse.

Furthermore, NATO's intervention in Kosovo led to the establishment of the international protectorate in the province. ${ }^{50}$ Eventually, the creation of an independent Kosovo was not seen merely as a buffer zone or outpost of NATO in Balkans, but more an ideological struggle between Russia and NATO. However, some argue that during the Kosovo crisis, relations between Russia and NATO survived all disputes. Despite distinct points of view, communication did not break down. On the contrary, both sides worked even closer together to find common ground. ${ }^{51}$

Overall, NATO's geopolitical discourse with regard to Kosovo crisis in 1999 stayed very positive. "Practical geopolitics" (NATO's political decisions) were strongly supported and partly influenced by the "popular geopolitics." Among specialists who represent "formal geopolitics," the 1999 bombings of Kosovo are seen as the most successful of NATO's operations after the end of the Cold War. NATO was able to amplify its military attacks on Yugoslavia because the Alliance had successfully created the perception that it was responding in a measured and

48 bbc.co.uk, "Nato strikes: Week two", April 12, 1999, Source: http://news.bbc.co.uk/2/hi/special_report/1998/kosovo2/317324.stm (accessed March 5, 2014).

49 cnn.com, "Solana stresses NATO resolve in Kosovo conflict", May 4, 1999, Source: http://www.cnn.com/WORLD/europe/9905/04/kosovo.solana/ (accessed March 5, 2014).

Spiegel.de, "Fertiger Plan für den Bodenkrieg", 26.04.1999, Source: http://www.spiegel.de/spiegel/print/d12771283.html (accessed March 5, 2014).

${ }^{50}$ Alexandra Gheziu, NATO in the "New Europe": The Politics of International Socialization after the Cold War, Stanford University Press (2005), 240.

51 Andreas Behnke, NATO's Security Discourse after the Cold War: Representing the West, Routledge; 1 edition (2012), 120. 
proportional way to the events on the ground. ${ }^{52}$ The bombings helped to propel the negotiations with Milosevic and his regime. The air campaign was changed to a ground campaign (peace keeping mission) because NATO demonstrated that the Alliance desired a diplomatic solution.

In late April 1999, NATO member states presented its new strategic concept (changes in the "practical and formal geopolitics") where lots of attention was paid to "the conflicts prevention and crisis management." 53 The Kosovo war had significant impact on the creation of the NATO strategy. This document is different from the previous ones with its intentions and NATO's perception of crisis. According to the new strategy NATO "will seek, in cooperation with other organizations, to prevent conflict, or, should a crisis arise, to contribute to its effective management, consistent with international law, including through the possibility of conducting non-Article 5 crisis response operations." ${ }^{, 54}$ It created a precedent and left some space for interpretations about non-Artcle-5 crisis response (for instance, any new threat could provide grounds for military action by the Alliance's forces). According to the Brookings think tank: "[..] the Alliance should provide a solid foundation for joint military action by allies when and wherever they deem such action to be necessary." 55 The success in the Balkans enhanced NATO's confidence and self-awareness about crisis management outside the Alliance borders. Consequently, NATO's geopolitical discourse towards Kosovo and the overall geopolitical tradition of "crisis manager" was very positive.

Additionally, Operation Allied Force was not limited to military strikes. After several years the idea of Kosovo independence among NATO members already started to appear in 2005. In the year 2006, NATO diplomats were firmly persuaded that "while Russia would be uncomfortable with Kosovo's independence they would still go with it." ${ }^{, 56}$ In the year 2007, the troika group, which consisted of the US, EU and Russia negotiated the future of Kosovo. The unilateral declaration of Kosovo's independence, supported by most NATO countries, came just

\footnotetext{
52 John Norris, Collision course: NATO, Russia, and Kosovo, Praeger Press (2005), 299

53 NATO strategic concept (1999); Source: http://www.nato.int/cps/en/natolive/official_texts_27433.htm (accessed March 8, 2014);

54 Ibid;

55 Ivo H. Daalder, "NATO, the UN, and the Use of Force", March 1999; Source: http://www.brookings.edu/research/papers/1999/03/globalgovernance-daalder (accessed March 2, 2014);

${ }_{56}$ Judah Tim, Kosovo: what everyone needs to know, Oxford University Press, USA (2008), 135-136.
} 
weeks after the Contact Group report had affirmed that there would be no imposed solution. ${ }^{57}$ The gridlock of negotiations between different parties was broken by the self-willed western countries' decision to support Kosovo's intention to become independent. Although Russia protested, NATO was ready to implement all financial and political measures to keep Kosovo's independence secured.

After the Kosovo war in 1999, air strikes gave way to KFOR ground forces that operated as the peacekeepers. Up to 2008 Western countries provided billions of dollars for postwar recovery and development. In the summer of June 2008, NATO agreed on the new KFOR tasks:

- Stand-down of the Kosovo Protection Corps;

- The creation of the Kosovo Security Force. ${ }^{58}$

This indicated a new stage of Kosovo's state development, when the Alliance member states were ready to help Kosovars to undertake full and independent control of their own sovereign state. NATO's acceptance of 'status before standards' in its dealings with the Kosovar leadership has been genuine and in some respects justified. ${ }^{59}$ NATO was hoping that with the close assistance and quick democratic development, Kosovo would achieve all standards needed for a modern state. NATO continued "to attach great importance to the implementation of standards in Kosovo, especially regarding the rule of law, the protection of ethnic minorities and communities, as well as the protection of historical and religious sites. ${ }^{\circ 60}$ Truly, Kosovo was an exceptional case which was extensively debated within NATO.

In this regard, the question of the Kosovo sovereignty divided NATO member states into two different camps. NATO's "practical geopolitics" turned out to be fragmented. The majority of NATO member states approved the confirmation of Kosovo's independence, the rest opposed it. Spain, Slovakia, Romania and Greece still do not recognize the status of Kosovo. The main purpose for their reaction is the contemporary domestic political and ethnic issues that these countries face. Nevertheless, NATO still tried to cooperate with Kosovo as one united Alliance.

\footnotetext{
57 James Hughes, "Russia and the Secession of Kosovo: Power, Norms and the Failure of Multilateralism", EuropeAsia Studies Vol. 65, No. 5, (July 2013), 1011.

58 NATO's role in Kosovo; Source: http://www.nato.int/cps/en/natolive/topics_48818.htm (accessed March 10, 2014).

${ }^{59}$ Derek Averre, "From Pristina to Tskhinvali: the legacy of Operation Allied Force in Russia's relations with the West", International Affairs 85: 3 (2009), 589.

${ }^{60}$ NATO Press release, "Statement by the North Atlantic Council after Kosovo's declaration of independence", February 18, 2008; Source: http://www.nato.int/docu/pr/2008/p08-025e.html (accessed March 10, 2014).
} 
As in 1999, "popular geopolitics" played an important role in establishing a certain NATO geopolitical discourse. The western media in February 2008 paid exclusive attention to the declaration of Kosovo's independence. During the month of February, BBC covered the story of Kosovo 79 times. BBC mostly analyzed the impact of Kosovo's independence on the Balkans region, Russia and NATO. ${ }^{61}$ Even though CNN wrote only 21 stories about Kosovo in one month, these articles were more positive rather than unbiased regarding the question of the independence of Kosovo. Some articles simply glorified NATO: "Kosovo's dream to become independent dates back decades, but only after NATO intervened militarily almost a decade ago did ethnic Albanians begin to feel their dream could become true."62 By contrast Der Spiegel mentioned Kosovo's case 39 times and stayed more or less impartial the entire time about the reaction of western countries, Serbia and Russia. ${ }^{63}$ Journals and newspapers often promoted a certain geopolitical discourse that served a political agenda which was more favorable to Kosovo's state rather than to Serbia. The western media and NATO member states became more concerned about the consequences of Kosovo's independence only when they all noticed that a similar discourse and strategy was applied by the Russians in Abkhazia and South Ossetia in the Caucasus.

Even though Kosovo with a support of western countries successfully declared its unilateral independence, NATO's entire geopolitical discourse could be understood as neutral. One the one hand, "popular geopolitics" covered positive news about Kosovo's independence, but on the other hand, "practical geopolitics" was represented as fragmented and dispersed. In addition, according to various specialists and academic writings, "formal geopolitics" of NATO was dichotomous - with positive and negative aspects. When some NATO member states were against the idea of the independence of Kosovo, the US successfully promoted and lobbied in

\footnotetext{
61 BBC.co.uk, "Recognition for new Kosovo grows", March, 18, 2008; Source: http://news.bbc.co.uk/2/hi/europe/7251359.stm (accessed, March 10, 2014).

62 Alessio Vinci, "Analysis: Kosovo now and then", CNN February 15, 2008, Source: http://www.cnn.com/2008/WORLD/europe/02/15/kosovo.vinci/index.html?iref=allsearch (accessed March 10, 2014).

${ }^{63}$ Der Spiegel, "Debatte um Unabhängigkeit: USA erkennen Kosovo an - Deutschland und viele EU-Staaten wollen mitziehen", March 18, 2008; Source: http://www.spiegel.de/politik/ausland/debatte-um-unabhaengigkeit-usaerkennen-kosovo-an-deutschland-und-viele-eu-staaten-wollen-mitziehen-a-536051.html (accessed March 10, 2014). Der Spiegel, "Pristina: Kosovo erklärt sich für unabhängig", March 17, 2008; Source: http://www.spiegel.de/politik/ausland/pristina-kosovo-erklaert-sich-fuer-unabhaengig-a-535810.html (accessed March 10, 2014).

Der Spiegel, "Reaktionen auf Kosovo-Unabhängigkeit: Europas neues Problemkind", March 17, 2008; Source: http://www.spiegel.de/politik/ausland/reaktionen-auf-kosovo-unabhaengigkeit-europas-neues-problemkind-a535852.html (accessed March 10, 2014).
} 
favor of Kosovo. Similar changes in NATO's geopolitical discourse could be observed in the crisis of Afghanistan.

\subsubsection{Afghanistan in crisis}

At the beginning, the articulation of NATO's geopolitical discourse abouts its participation in the campaign in Afghanistan was more negative than positive. A few days after 9/11, NATO's press issued a release that said "NATO is not planning the invasion of Afghanistan, or of any other country." ${ }^{64}$ At that time, NATO as an institution was not effectively able to act and support the US military campaign in Afghanistan. Nevertheless, during the first month after the 9/11 events, NATO was ready to define its initial role and create measures with which it would participate in the new fight against terrorism. ${ }^{65}$ According to NATO "formal geopolitics" (NATO strategic community and specialists) and "practical geopolitics", Lord Robertson, the NATO Secretary General, NATO agreed to:

- Enhance intelligence sharing and co-operation;

- Provide assistance to Allies and other states which are or may be subject to increased terrorist threats;

- Enhance the security for the U.S. and allied facilities;

- Backfill selected Allied assets in NATO's area of responsibility that are required to directly support operations against terrorism;

- Provide blanket overflight clearances for the United States and other Allies' aircraft;

- Provide access for the United States and other Allies to ports and airfields on the territory of NATO nations for operations against terrorism;

- To deploy NATO's Standing Naval Forces to the Eastern Mediterranean;

- To deploy the NATO AWACS. ${ }^{66}$

Since 9/11, NATO has endorsed a whole package of initiatives and measures. NATO actively supported the U.S. military campaign - Operation Enduring Freedom. A greater role of the Alliance was set up only in 2003 when NATO became the official lead organization behind

64 NATO Press release, "Statement by the NATO Spokesman", September 13, 2001; Source: http://www.nato.int/DOCU/pr/2001/p01-125e.htm (accessed March 12, 2014).

${ }^{65}$ Sten Rynning, NATO in Afghanistan: The Liberal Disconnect, Stanford Security Studies (2012), 45.

${ }^{66}$ NATO Press, "Statement to the Press by NATO Secretary General, Lord Robertson, on the North Atlantic Council Decision On Implementation Of Article 5 of the Washington Treaty following the 11 September Attacks against the United States", October 4, 2001; Source: http://www.nato.int/docu/speech/2001/s011004b.htm (accessed March 12, 2014). 
ISAF. $^{67}$ Already in 2002 during the NATO Prague summit the Alliance member states agreed to "assist the Afghan government in restoring security in Kabul and its surroundings." 68 Based on the Bonn Agreements and the Prague summit NATO was ready to secure and stabilize Afghanistan with close support for the indigenous government, and ensure safety for the multiethnic society. Notwithstanding, the mission's activities were geographically limited to the security of Afghanistan's capital and its surrounding area. In 2004 the tasks of the NATO expanded and by then the Alliance started to "assist the central Afghan government in confronting domestic challenges such as narco-trafficking, insurgents and militias." ${ }^{, 69}$ Until 2005 NATO's performance in Kabul and its surroundings was successful and effective. NATO member states pushed the Taliban out of the strategic areas, an indigenous government was secured and ISAF's casualties exceeded to no more than seventy per year (many of them died due to non-violent conditions). ${ }^{70}$ Due to its successful performance and well organized "formal and practical geopolitics" work, the Alliance also had support from the mass media, or in other terms, the "popular geopolitics."

From the beginning, "popular geopolitics" played a fundamental role in reflecting the U.S. and its Allies campaign in Afghanistan and shaping societies' perception of the war against terrorism. This can be illustrated by an analysis of the quantity of western media's articles which were based on 'terrorism' or on 'terrorism in Afghanistan' (see Table Nr. 3). For instance, three months after the 9/11 events BBC news wrote only 98 stories about terrorism in Afghanistan and 2016 news about terrorism itself. Similarly, the German newspaper Der Spiegel, in the same period wrote 322 stories about terrorism and only 15 articles about terrorism in Afghanistan. After the tragic events in New York, one of the main newspapers in the U.S., The New York Times wrote a record amount of news about terrorism - 2420 times, and as the offset, only 908 stories about terrorism in Afghanistan.

\footnotetext{
${ }^{67}$ Sten Rynning, 44.

${ }^{68}$ Prague Summit Declaration Issued by the Heads of State and Government participating in the meeting of the North Atlantic Council in Prague on 21 November 2002; Source: http://www.nato.int/docu/pr/2002/p02-127e.htm (accessed March 12, 2014).

${ }^{69}$ Andreas Behnke, NATO's Security Discourse after the Cold War: Representing the West, Routledge; 1 edition (2012), 166.

${ }^{70}$ Appendix 7, Table Nr. 6.
} 
Table Nr. 3 The western media`s coverage of a 'terrorism' and the 'terrorism in Afghanistan'

\begin{tabular}{|c|c|c|c|c|}
\hline \multirow{2}{*}{} & \multicolumn{2}{|c|}{$\mathbf{1 1 / 0 9 / 2 0 0 1 - 1 1 / 1 2 / 2 0 0 1}$} & \multicolumn{2}{c|}{$\mathbf{1 1 / 0 9 / 2 0 0 2 - 1 1 / 1 2 / 2 0 0 2}$} \\
\cline { 2 - 5 } & 'terrorism' & $\begin{array}{c}\text { 'terrorism in } \\
\text { Afghanistan' }\end{array}$ & 'terrorism' & $\begin{array}{c}\text { 'terrorism in } \\
\text { Afghanistan' }\end{array}$ \\
\hline BBC & 2016 & 98 & 701 & 8 \\
\hline Der Spiegel & 322 & 15 & 165 & 96 \\
\hline The NY Times & 2420 & 908 & 602 & 2 \\
\hline
\end{tabular}

Source: made by the author based on news data

The September 11 events changed the way Americans and Europeans viewed the world. In Table Nr. 3 the given data of the same period, but one year later, substantiates that attention to terrorism which was originally coming from Afghanistan dramatically dropped. However, the media still continued publishing a volume of articles about terrorism itself. The mass paranoia towards terrorism created a new image of the menace, which became the main challenge to western governments. The "practical geopolitics" (the policy makers) and "formal geopolitics" (NATO strategic community) faced the pressure from "popular geopolitics" (the mass media) and started to initiate NATO's new geopolitical discourse towards terrorism.

Moreover, the September 11 attacks had significant impact on the institutional perspective of NATO in contrast to stability management in 1990s. After 9/11 NATO became more concerned about menaces, particularly ones aimed at the Alliance. Consequently, the Terrorism Threat Intelligence Unit was established which worked at NATO HQ in Brussels. In addition, the allies agreed "to implement a series of policies aimed at enhancing their collective ability to monitor and act against individuals and groups with alleged links to organized crime and terrorist organizations." ${ }^{, 71}$ Consequently, after the 9/11 attacks, the new geopolitical tradition of “crisis manager" was ultimately justified within NATO institutions ("formal geopolitics"), decision makers ("practical geopolitics") and the media ("popular geopolitics").

NATO's first overseas missions tested its capabilities to deploy military units far from its boundaries, and verify its capacity to stabilize and reconstruct a failed state. The successful first few years changed the perception of NATO - the Alliance appeared as the global policeman with

\footnotetext{
${ }^{71}$ Alexandra Gheziu, NATO in the "New Europe": The Politics of International Socialization after the Cold War, Stanford University Press (2005), 243
} 
the United States in front. NATO's involvement in Afghanistan holds broader international implications with regard to the effectiveness of international strategies to combat terrorism and insurgency. ${ }^{72}$ Notwithstanding, NATO was not entirely able to function without international partners, particularly Russia.

To sum up, in the first years of the military operation in Afghanistan, NATO's geopolitical discourse could be explained as positive. With the support from the mass media, NATO strategy and decisions makers achieved temporary success in Kabul and its surroundings. However, after the year 2005 the situation started to change and NATO entered a protracted war against the Taliban and terrorism itself.

After ten years, NATO officially declared that "the transition to full Afghan security responsibility is due to be completed at the end of 2014, when ISAF's mission will end."73 However, at this moment in spring, 2014 NATO is putting a lot of pressure on Afghanistan to retain its presence, but the results are still controversial. According to NATO Secretary-General Anders Fogh Rasmussen, "if there is no agreement [between NATO and Afghanistan], there will be no NATO troops in Afghanistan after 2014."74 On the one hand, Afghanistan's society is exhausted after thirteen years of NATO military operations. Moreover, according to the UN annual reports, in the previous year the casualties among civilians increased $14 \%{ }^{75}$ The NATO strategic community and decision makers have faced a constant political, social resistance from Afghan groups and politicians who were also influenced by the presidential elections held in spring 2014. On the other hand, NATO is still attempting to sustain its military presence in Afghanistan after 2014. First of all, NATO is seeking to secure its successful work on the Provincial Reconstruction Teams and Afghanis Training Mission. And secondly, NATO,

\footnotetext{
72 Ivan Dinev Ivanov, Transforming NATO: New Allies, Missions and Capabilities, Rowman \& Littlefield Publishers, (2011), 201

73 Official website of NATO, "NATO and Afghanistan"; Source: http://www.nato.int/cps/en/natolive/topics_8189.htm? (accessed March 14, 2014).

74 David S. Cloud, "NATO puts pressure on Afghanistan to sign troop agreement", Los Angeles Times, February 26, 2014; Source: http://www.latimes.com/world/worldnow/la-fg-wn-nato-afghanistan20140226,0,6307655.story\#axzz2vxFgISK3 (accessed March 14, 2014).

${ }^{75}$ UN News Center, "Civilian casualties in Afghanistan up 14 per cent last year, says new UN report", February 8 , 2014; Source: http://www.un.org/apps/news/story.asp/story.asp?NewsID=47107\&Cr=Afghan\&Cr1=\#.UyMwiT95Meg (accessed March 14, 2014).
} 
especially the U.S., wants to keep their military bases operating and ensure their presence in Afghanistan to maintain a balance of power in the region.

Within NATO's "formal” and "practical” geopolitical discourses, the stabilization of Afghanistan is both a domestic as well as geopolitical problem. ${ }^{76}$ First of all, the previous several years have demonstrated that terrorism is not limited to the boundaries of Afghanistan, but has spread and been consolidated in other countries, such as Pakistan. Secondly, reaching agreement regarding allies` contributions to the Afghanistan mission has become increasingly complicated. ${ }^{77}$ Within NATO allies have disagreed and found difficulties in determining each member states" contribution to the mission. NATO's "formal" and especially "practical" geopolitics could not find consensus with each other. Different perceptions within the strategic community and among decision makers have increased divisions within NATO towards the Afghanistan crisis.

Since 2005, NATO has turned to counterinsurgency to win the hearts and minds of the indigenous populations; thus the mission has expanded. NATO's leadership was too focused on liberal convictions in the abstract and too unaware of the mission's consequences. ${ }^{78}$ The divisions between NATO member states have been a fundamental factor that impacted NATO's geopolitical discourse regarding the mission in Afghanistan. Internal disputes and the occasional independent act of some NATO members, particularly the United States, upset external actions in Afghanistan and ultimately overrode the principles of the Atlantic political leadership. Inefficient unilateral American policy towards Afghanistan distracted the strategy of the Alliance as a whole. Contemporary relations between Afghanistan and NATO have switched from bad to worse.

Excluding Afghanistan's internal divisions and counterinsurgency, the media, or in other terms, "popular geopolitics" is another fundamental factor that has impacted NATO's geopolitical discourse. The early western societies' enthusiasm was transformed by anxiety and later on, during the economic crisis, deep public disappointment became a normal phenomenon. The media is a key factor informing the western population more often about the failures in Afghanistan than about successes. In the last several years the fatalities of NATO troops have

\footnotetext{
76 Andreas Behnke, NATO's Security Discourse after the Cold War: Representing the West, Routledge; 1 edition (2012), 170.

77 Ivan Dinev Ivanov, Transforming NATO: New Allies, Missions and Capabilities, Rowman \& Littlefield Publishers, (2011), 202.

${ }^{78}$ Sten Rynning, NATO in Afghanistan: The Liberal Disconnect, Stanford Security Studies (2012), 214.
} 
reached the same amount of casualties as in the first eight years (2001-2008) of the war (see appendix 7). Furthermore, the media has published contemporary interviews with Afghanistan's president who declares that "the entire NATO exercise was one that caused Afghanistan a lot of suffering, a lot of loss of life, and no gains." 79 The hostility of Afghanistan's politicians and society is constantly published in various newspapers and mostly it is negative content news rather than positive. ${ }^{80}$

Some could argue that the media tends to manipulate negative news just in order to receive more attention from the daily readers. However, the last two years of the UN reports also noted negative developments and confirmed increasing fatalities among Afghani civilians. ${ }^{81}$ Undoubtedly, in several respects Afghanistan has made progress by improving the education system and national health service, and by expanding infrastructure and roads, but such advances do not represent the overall development of the economic, military and political situation. In light of the UN reports, as well as media and other reports, the inferences from NATO's official discourse about the improving conditions and representation of the contemporary situation on the ground in Afghanistan appear to be inaccurate or even deceptive.

Consequently, taken as a whole, NATO's geopolitical discourse towards the crisis in Afghanistan could be defined as negative. Division within NATO and criticism from the media and societies' skepticism eventually transformed NATO's positive geopolitical discourse in the first years of the military campaign in Afghanistan to negative in the last few years. According to Dr. Ieva Karpaviciute, a special Lithuanian attaché to NATO HQ, the military operation in Afghanistan was "the most expansive in terms of lives and expenses." 82 It had significant impact on NATO member states, especially their societies, which has become tired of the long-lasting war and anxious about wasted resources in the overseas mission. Political and strategic internal divisions in NATO propose that debates about "the global NATO" must be put to an end. In

\footnotetext{
${ }^{79}$ Yalda Hakim, “Afghanistan's Hamid Karzai says NATO caused great suffering”, BBC, October 7, 2013; Source: http://www.bbc.com/news/world-24433433 (accessed March 14, 2014).

80 Emma Graham-Harrison, "Relationship between Hamid Karzai and US grows ever more poisonous", The Guardian, January 28, 2014; Source: http://www.theguardian.com/world/2014/jan/29/relationship-hamid-karzai-usafghanistan

The New York Times, "In Afghanistan, Protests Over Disposal of Korans", February 21, 2012; Source: http://www.nytimes.com/slideshow/2012/02/21/world/asia/20120222-

AFGHANISTAN.html?ref=northatlantictreatyorganization (accessed March 14, 2014).

${ }^{81}$ UN reports about Afghanistan; 2013: http://daccess-dds-

ny.un.org/doc/UNDOC/GEN/N13/571/98/PDF/N1357198.pdf?OpenElement and 2012: http://daccess-ddsny.un.org/doc/UNDOC/GEN/N12/239/52/PDF/N1223952.pdf?OpenElement (accessed March 14, 2014).

${ }^{82}$ Appendix 3, Interview Nr. 2
} 
other words, disputes between all three different types of geopolitical discourses (formal, practical and popular) suggest that the future of NATO's geopolitical tradition as a "crisis manager" is doubtful. It is uncertain when a comparable NATO military operation might be organized in another overseas territory. Tensions in Mali, the Central Africa Republic, and Yemen presuppose the notion that only major NATO member states, mostly the U.S., UK and France, might take action. Uncertain victory in Afghanistan left many Alliance member states dubious about their successful contribution. The similar situation could be observed during the Libyan crisis in 2011.

\subsubsection{The Libyan crisis}

In 2011, an application of the UN SC resolution 1973 came only after the Arab League had agreed to support a no-fly zone over Libya. According to paragraph IV of the resolution, the UN authorizes NATO "to take all necessary measures [...] to protect civilians and civilian populated areas under threat of attack in the Libyan Arab Jamahiriya, including Benghazi [...]."83 However, this official document does not include any definitions and words related to offensive military actions. On March 19, 2011 when the NATO-led coalition started to launch an attack on the Libyan government and military, disputes within the international community appeared, revealing that the resolution, especially the phrase "to take all necessary measures," was interpreted differently by separate countries and NATO.

NATO intervention in Libya, under the mantle of "responsibility to protect," came at a crucial turning point in the history of the world. ${ }^{84}$ The vital aim of NATO was to stop the Libyan government from using force against its own people. Others argue that NATO's entry into Libya was the result of "a bloody stalemate" between opposing sides in Libya. ${ }^{85}$ The concept of "protecting the Libyan people" was also interpreted differently within NATO. First of all, in order to halt the advancing Libyan army the Alliance bombed strategic targets, such as military airfields, military bases, and motor pools. NATO's "formal" and "practical" geopolitical discourses towards Libya gradually intensified and eventually NATO launched air strikes simultaneously coordinated with the opposition troops' ground attacks. In addition, significant

83 UN SC resolution Doc S/RES/1973, paragraph IV (March 17, 2011); Source: https://www.un.org/News/Press/docs/2011/sc10200.doc.htm (accessed March 21, 2014).

${ }^{84}$ Campbell Horace, Global NATO and the Catastrophic Failure in Libya, Monthly Review Press (2013), 256.

${ }^{85}$ Alison Pargeter, Libya: The Rise and Fall of Qaddafi, Yale University Press (2012), 236. 
volumes of supply drops supported the opposition fighters. Ultimately, Western leaders sought to get rid of the Gaddafi regime and replace it with a transitional government.

According to Ivo H. Daalder, the U.S. Permanent Representative to NATO, and James G. Stavridis, the Supreme Allied Commander Europe and Commander of the U.S. European Command, "the alliance responded rapidly to a deteriorating situation that threatened hundreds of thousands of civilians rebelling against an oppressive regime." ${ }^{~} 66$ Undoubtedly, the NATO campaign against Gaddafi forces saved thousands of innocent civilians and brought temporary security to Libya. Although there were miscalculations in the air strikes and casualties among civilians increased, NATO's "formal and practical" geopolitical discourse was aimed to protect civilians, enforce a no-fly zone and continue with the weapons embargo. Paradoxically, some NATO member states, particularly France, were providing weapon supplies to the opposition forces. The Alliance was using double standards and instead of being a mediator in the Libyan conflict, it fully supported the opposition forces. Nevertheless, this did not limit NATO's capabilities and eventually, according to NATO's "practical geopolitical” discourse, Operation Unified Protector in Libya showed that:

NATO's political unity is improving, [but] more work must be done. NATO allies overcame their early differences on Libya and forged a course of action acceptable to all. Every ally contributed to the operation through NATO's command structure, and no allies restricted the use of their personnel assigned to NATO command centers. ${ }^{87}$

Notwithstanding the official opinion of NATO, the mission in Libya revealed the deficiencies of the Alliance and its strategic concept (2010), when the gap between the coalition of the willing (the US, France and the United Kingdom), who always drive military campaigns, and the rest of the member states became wider than any time before. Operation Unified Protector was not run by "political NATO" (practical geopolitics), but rather "command-andcontrol NATO" (formal geopolitics), where again the coalition of the willing was leading the agenda setting and whole military campaign. ${ }^{88}$ The contribution of other members was limited due to their lack of military capabilities and internal political decisions to avoid another potential long-lasting war overseas. If in Afghanistan the Alliance was working more or less as one team, then during the Libyan crisis NATO appeared fragmented (this later appears in Afghanistan as

\footnotetext{
${ }^{86}$ Ivo H. Daalder and James G. Stavridis, "NATO's Victory in Libya The Right Way to Run an Intervention", Foreign Affairs vol 92, Nr. 2, (March/April 2012), 2.

${ }^{87}$ Ivo H. Daalder and James G. Stavridis, 4.

${ }^{88}$ Sten Rynning, NATO in Afghanistan: The Liberal Disconnect, Stanford Security Studies (2012), 44.
} 
well, see sub-chapter "4.1.2. Afghanistan in crisis"). Together with a fragmentation within NATO, the geopolitical discourse towards the crisis in Libya and the overall NATO geopolitical tradition of "crisis manager" decreased dramatically. Eugeniusz Smolar, a senior fellow at the Polish Institute of International Affairs, distinguishes five fundamental aspects demonstrating the Alliance's differences towards the Libyan crisis:

- France unilaterally recognized the rebels in Benghazi as an alternative Libyan government and argued for military intervention in order to support them;

- Germany abstained during the vote in the Security Council, breaking the allies' solidarity and siding with countries such as China and Russia;

- France and the UK assumed a leading role by starting a military campaign practically on their own without referring the matter;

- Not just Germany but several other countries, including Poland, which had been interventionist until now, refused to participate in any military activities. ${ }^{89}$

Furthermore, in analyzing NATO's "practical geopolitical” discourse, political disputes over the Libyan campaign mostly appeared between the US and France. France pushed the American government to contribute to the campaign and help the European Allies to deal with the Gaddafi regime. At the same time (2011), NATO was simultaneously involved in the peace keeping mission in Kosovo and fighting against terrorism in Afghanistan, where thousands of NATO forces were still deployed.

In the same year, the Financial Times and the Harris Data Base did a survey in the U.S. and the other Alliance member states regarding the military campaign in Libya. In the table below, the survey shows the striking skepticism of NATO member states' public opinion towards the overseas mission. However, even the success in Libya did not alter and reshape beliefs of societies. In 2011, mostly all NATO member states were still in an economic recession or slowly recovering after the recent economic crisis. Skepticism of the societies and the neglect of the public opinion prove that NATO's decision to go against Libya was based on the unilateral political decisions of a few ambitious Alliance countries (France and the UK) which were eventually criticized by "popular geopolitics." On the one hand, though the military operation in Libya was successfully done under the NATO flag, future participation in overseas missions as a

89 Eugeniusz Smolar, “Transatlantic relations and NATO”, European View 10:127-135, Centre for European Studies(2011), 133-134. 
united Alliance became less likely. On the other hand there is no doubt that NATO is a unique military alliance which is capable of solving such a crisis as in Libya or implementing UN SC resolutions.

Overall, NATO's geopolitical discourse in Libya could be understood as neutral. Even though Gaddafi's regime was changed, internal disputes within NATO and criticism from “popular geopolitics" downgraded NATO's geopolitical discourse as a whole to neutral neither positive, nor negative. The NATO campaign successfully ended Gaddafi's dictatorship, but the contemporary situation on the ground in Libya is still disturbing. A few years after the start of the revolution, Libya is still writhing in crisis. ${ }^{90}$ Several months ago, the Special Representative and Head of the UN Support Mission in Libya (UNSMIL), Tarek Mitri, claimed that the situation in the Libya is extremely dangerous. ${ }^{91}$ Hence, competing militias, controversial political reforms, and rivalry between the political elites and international corporations characterize contemporary post-Qaddafi Libya. It is doubtful what impact NATO's invasion had. On the one hand it achieved temporary goals - it stopped atrocities towards indigenous people, but on the other hand, in the longer-term it failed to secure post-Qaddafi Libya.

Table Nr. 4 Public opinion towards the crisis in Libya

\begin{tabular}{|l|l|l|l|}
\hline \multirow{2}{*}{} & \multicolumn{3}{|c|}{ Survey of Financial Times/Harris (March-April 2011) } \\
\cline { 2 - 4 } & Support $(\%)$ & Neither (\%) & Oppose (\%) \\
\hline US & 32 & 31 & 37 \\
\hline Britain & 36 & 28 & 32 \\
\hline France & 40 & 28 & 39 \\
\hline Germany & 34 & 27 & 50 \\
\hline Italy & 29 & 21 & 34 \\
\hline Spain & 37 & 29 & 36 \\
\hline
\end{tabular}

Source: Harris Data Base: http://www.harrisinteractive.com/vault/HI_UK_Corp_News_FTHarris-Poll-Apr-2011.pdf (accessed March 20, 2014).

\footnotetext{
${ }^{90}$ Alison Pargeter, Libya: The Rise and Fall of Qaddafi, Yale University Press (2012), 248

${ }^{91}$ UN News Center, "Precarious security situation in Libya shows need for dialogue with militias - UN envoy", December 9, 2013; Source: http://www.un.org/apps/news/story.asp//story.asp?NewsID=46696\&Cr=libya\&Cr1=\#.UzTDZqh5Meg (accessed March 27, 2014)'
} 


\subsection{Russian geopolitical discourses}

This sub-chapter will concentrate on an analysis of Russian geopolitical discourse towards crises in Kosovo, Afghanistan and Libya. The same method that was applied NATO's geopolitical discourse will be used. "Formal geopolitics" (analyses of think tanks, specialists, etc.), "practical geopolitics" (the decisions of policy makers, official statements, documents, strategies and speeches) and "popular geopolitics" (the discourse of the media and surveys) will be identified and scrutinized. Thereafter, the findings will be compared and contrasted with NATO's geopolitical discourse.

\subsubsection{The Kosovo crisis}

For the last few centuries Russia has had interests in the Balkans region. However, according to Vadim Volovoj, the senior specialist of the Centre of Geopolitical Studies, during "Yeltsin's times Russia was strategically weak and it could not play an important role in the international arena", including the Balkans. ${ }^{92}$ Russian concerns in the Balkans were debated only in the context of establishing a close relationship with the Former Republic of Yugoslavia (FRY). ${ }^{93}$ The Russian Federation believed that keeping close ties with FRY would help to maintain the balance of power and prevent the presence of other international actors in the region. However, the final outcome was opposite Russian expectations.

From its inception, Russia's geopolitical discourse was hostile and critical to NATO's military operation against FRY. This could be linked to Russia's past experiences in Afghanistan and Chechnya (1994-1996) when the application of hard power did not help to solve ethnic problems. Additionally, Russia was deeply concerned about the air strikes in FRY where Russian business was interrupted. The introduction of the EU embargo on "prohibiting the sale and supply of petroleum and petroleum products to the FRY" led to Russian financial losses. ${ }^{94}$ Despite these facts Russia still sought to be involved in the international decision making which aimed at rebuilding the devastated areas.

During 1999 Russia changed its own "practical geopolitical" position at least a few times. At that time the Russian President Boris Yeltsin faced great diplomatic pressure from NATO

\footnotetext{
92 Appendix 4, Interview Nr. 3.

93 Дмитрий Тренин and Екатерина Степанова, Косово: международные аспектыл кризиса, Moscow Carnegie Center, 1999, 258 Source: http://carnegieendowment.org/files/cosovomnaspekty.pdf (accessed March 3, 2014).

${ }^{94}$ EU Commission's regulation "No 900/1999 prohibiting the sale and supply of petroleum and petroleum products to the Federal Republic of Yugoslavia"; lex.europa.eu/LexUriServ/LexUriServ.do?uri=COM:1999:0455:FIN:EN:PDF (accessed March 6, 2014).
} 
member states, particularly from the U.S. And even though on June 23, 1999 Russia affirmed its commitment to full implementation of the provisions and goals of the UN resolution UNSCR 1244, Russia's participation in decision-making remained secondary. ${ }^{95}$ After five months NATO and Russian ambassadors met once again and emphasized "their commitment to full implementation of the provisions and goals of UNSCR 1244."96 Furthermore, both sides also agreed "to cooperate closely in ensuring the protection of Kosovo's minorities and the establishment of a multi-ethnic, democratic society." 97 Official agreements however did not fully represent the real situation on the ground in Kosovo. Russia's political elite ("practical geopolitics") and its "formal geopolitical" position as a whole were still overwhelmingly against NATO's intervention. Although both parties agreed that there would be Russian troops present in Kosovo, all of them were "spread among 45,000 NATO peacekeepers." 98 After long months of endless negotiations between both sides, Russia was not even awarded its own sector in Kosovo.

Moreover, all diplomatic agreements, negotiations and NATO military operations against Serbia were constantly monitored by the Russian media. In contrast to the NATO "popular geopolitics", the Russian "popular geopolitics" (the media) appeared biased and one-sided in its coverage of the Kosovo events. In an interview, Professor Boris Barkanov, a lecturer in Political Science at West Virginia University, claimed that during NATO's air strikes campaign "there was a very broad consensus among Russians, both between the public and the elite." $" 99$ Western countries, particularly NATO member states, were seen as aggressors. The Russian media was one of the main sources for information about the NATO campaign in FRY and a serious generator of the certain Russian geopolitical discourse. For instance, in more than two months (March 23 - June 10, 1999) the newspaper Kommersant wrote 147 stories about Kosovo. Many of the articles criticized NATO for its intervention, for its activities supporting the KLA, for the

\footnotetext{
${ }^{95}$ Statement by the NATO-Russia Permanent Joint Council on the Security Situation in Kosovo (June 23, 1999); Source: http://www.nato.int/cps/en/natolive/official texts_27424.htm?selectedLocale=en (accessed March 6, 2014); UN SC resolution 1244 (1999); Source: http://daccess-ddsny.un.org/doc/UNDOC/GEN/N99/172/89/PDF/N9917289.pdf?OpenElement (accessed Feb 28, 2014).

${ }_{96}$ Press statement: meeting of the NATO-Russia Permanent Joint Council at Ambassadorial level (November 17, 1999); Source: http://www.nato.int/cps/en/natolive/official_texts_27413.htm?selectedLocale=en (accessed March 6, 2014).

${ }^{97}$ Ibid.

${ }^{98}$ John Norris, Collision course: NATO, Russia, and Kosovo, Praeger Press (2005), 290.

${ }^{99}$ Appendix 5, Interview 4.
} 
constantly increasing number of civilian casualties, etc. ${ }^{100}$ In addition, Kommersant stayed positive about Serbia, Milosevic and the high morale of the Serbian people. ${ }^{101}$ A similar situation could be recognized in another Russian newspaper - Pravda. Even though Pravda wrote less (only 52 articles in more than two months period), the content was similar. The newspaper was more positive about FRY than about NATO. ${ }^{102}$ However, it was not as critical as Kommersant. Eventually, the Russian "popular geopolitics" mostly can be characterized as an anti-NATO, proRussian and pro-Serbian. Consequently, the opinion of the readers was gradually influenced by the biased media, which served as an important contributor to Russian geopolitical discourse towards the crisis in Kosovo.

Moreover, in another interview, the senior counselor of the Russian embassy in the U.S. Denis Gonchar claimed that "in 1999 the invasion of Kosovo was the biggest violation of law. NATO intervention violated international law towards Serbians and after bombing Serbia relations between Russia and NATO were frozen."103 Despite NATO's decision in March 1999 to go ahead with OAF without a UN Security Council resolution, the question of acting without UN backing remained controversial within the NATO alliance. On the other hand, the Alliance member states knew that in order to avoid Russian opposition in UN Security Council, rapid decision-making was needed. In 1999 the NATO invasion and geopolitical discourse towards the crisis in Kosovo did more damage to relations between NATO and Russia than any other event in the 1990s.

Looking from the general perspective, if NATO's geopolitical discourse as a whole was evaluated as very positive, then with regard to the evidence and its analysis, the Russian geopolitical discourse towards the crisis in Kosovo could be depicted as very negative. The active involvement of NATO's "formal and practical geopolitics" led to the limitations on and

\footnotetext{
100 Афанасий Сборов, “Милошевич раздражает многих”, March 26, 1999; Source: http://www.kommersant.ru/doc/215622?isSearch=True (accessed March 6, 1999).

Геннадий Сысоев, “Война без правил”, April 6 , 1999; Source: http://www.kommersant.ru/doc/15336?isSearch=True (accessed March 2014).

101 Kommerstant.ru, “Я теперь знаю, как бывает в аду”, March 26, 1999; Source: http://www.kommersant.ru/doc/215619?isSearch=True (accessed March 6, 1999).

102 Pravda.ru, "Сегодня представители блока левых сил Украины пикетировали посольство США”, Маrсh 25, 1999; Source: http://www.pravda.ru/news/world/25-03-1999/904126-0/ (accessed March 6, 2014).

Pravda.ru, “ Представитель СРЮ обвиняет НАТО в сговоре с Армией освобождения Косово с целью усиления влияния Альянса на Балканах", April 1, 1999; Source: http://www.pravda.ru/news/world/01-041999/900472-0/ (March 6, 2014).

Pravda.ru, “Силовой Метод Решения Проблемы Косово Завел Нато В Тупик”, March 6, 1999; Source: http://www.pravda.ru/news/world/06-04-1999/900558-0/ (accessed March 6, 2014).

${ }^{103}$ Appendix Nr. 2, Interview Nr. 1.
} 
hostility of the Russian decision and strategy makers. Even though the Russian geopolitical discourse could not respond adequately to NATO's strong geopolitical discourse, a precedent was created. Among certain Russian politicians and strategy makers NATO was started to be seen as a threat. Moscow had no way to strategically or legally contain NATO actions that it didn't like. Consequently it created discourses of fear and dissent. Russia had serious concerns about NATO's military activities. Russia seemed to consider that there were only two options: either to accept NATO's role or to challenge it. ${ }^{104}$ Russia gradually started to increase its focus upon Europe and build a strong and self-reliant state. The changes in the Russian geopolitical discourse towards the crisis in Kosovo could be also noticed almost a decade later, when Kosovo declared its independence in 2008.

Already in February 2007 the Russian president, Vladimir Putin, expressed Russia's importance in European affairs. His controversial speech at the Munich security conference emphasized two matters of fundamental importance: first, Russia sought to play greater role in the international arena and secondly, Russia would be pursuing its own independent policy based on its political interests. ${ }^{105}$ In January 2008, just one month before the declaration of Kosovo's independence, Moscow issued a new foreign policy strategy document. Relations between NATO and Russia were recognized as an equal partnership based on international law and the balance of power - "one's security at the expense of security of the Russian Federation" could not be tolerated. ${ }^{106}$ In addition, Russia still "maintains its negative attitude towards the expansion of NATO."107 The active role of NATO towards the independence of Kosovo and ignoring of Serbian interests challenged Russian geopolitical discourse towards European affairs.

Russia saw its multilateral engagement over Kosovo as a strategic action to counterbalance and compensate for its weakness vis-a-vis NATO. ${ }^{108}$ Russia complained about the violation of Serbian rights, the crimes of the KLA and so on. Furthermore, Russia was

104 Albrecht Shnabel and Ramesh Thakur, Kosovo and the challenge of humanitarian intervention: selective indignation, collective action, and international citizenship, United Nations University Press (2000), 105

105 Oliver Rolofs, "A Breeze Of Cold War", MSC, February 2007; Source: https://www.securityconference.de/en/about/munich-moments/a-breeze-of-cold-war/ (accessed March 10, 2014).

106 The Foreign Policy Concept Of The Russian Federation (2008); Source: http://archive.kremlin.ru/eng/text/docs/2008/07/204750.shtml (accessed March 10, 2014).

${ }^{107}$ Ibid.

${ }^{108}$ James Hughes, "Russia and the Secession of Kosovo: Power, Norms and the Failure of Multilateralism", EuropeAsia Studies Vol. 65, No. 5, (July 2013), 992. 
opposed to the Kosovo declaration because the UNSC Resolution 1244 did not justify the independence of Kosovo. Later, Russia recognized the failure of troika negotiations (the US, EU and Russia) and argued that the unilateral declaration of Kosovo's independence, which was actively supported by NATO member states, was in violation of all previous official agreements. As in 1999, Russia's opinion was not taken into account - NATO again acted unilaterally. In an interview with the senior specialist from the Center of the Geopolitical Studies claimed that at this time "Russia was rather influential in the international arena, but still Russia could not allow itself to rival seriously western countries."109 Nevertheless, Russia tried to show that its geopolitical discourse towards Kosovo's independence and NATO was rigorous.

On February 17, 2008 the Russian Ministry of Foreign Affairs declared that the independence of Kosovo was "violating the sovereignty of the Republic of Serbia, the Charter of the United Nations, UNSCR 1244" and other international agreements. ${ }^{110}$ Russian officials believed that Kosovo's independence would be the cause of the regional conflicts. Furthermore, Moscow urged the international community to respond to separatism in Kosovo and punish everyone connected to it. Consequently, according to the Senior Counselor Denis Gonchar from the Russian Embassy in Washington D.C., the Russian Federation still does not recognize Kosovo as an independent state. ${ }^{111}$

Russia's position on Kosovo had already been consistently supportive of Serbia, but after January 2008, on the cusp of Kosovo's declaration of independence, Russia tied itself strategically even more closely to Serbia. ${ }^{112}$ However, others argue that actually for Russia, Kosovo is on the periphery of its interests. Thus Moscow did not adequately respond to Kosovo's independence. ${ }^{113}$ Professor Boris Barkanov has a similar perspective: the independence of Kosovo did not change Russia's discourse so much. ${ }^{114}$ Nevertheless, one point is clear - Russian "formal and practical discourses" were dissatisfied with NATO's monopolization of European affairs and its unilateral decisions. By the year 2008, the

\footnotetext{
${ }^{109}$ Appendix 4, Interview 3.

110 The official site of the Ministry of the Foreign Affairs of the Russian Federation, "Statement by Russia's Ministry of Foreign Affairs on Kosovo", February 17, 2008; Source: http://www.mid.ru/bdomp/brp_4.nsf/e78a48070f128a7b43256999005bcbb3/041c5af46913d38ac32573f30027b380! OpenDocument (accessed March 10, 2014).

${ }^{111}$ Appendix 2, Interview Nr. 1.

112 James Hughes, "Russia and the Secession of Kosovo: Power, Norms and the Failure of Multilateralism", EuropeAsia Studies Vol. 65, No. 5, (July 2013), 1010.

${ }^{113}$ Appendix 4, Interview 3.

${ }^{114}$ Appendix 5, Interview 4.
} 
centralization of political power could be noticed in the Russian geopolitical discourse towards the crisis in Kosovo. The media, which are a fundamental element of "popular geopolitics", became closely monitored by and even dependent on the Kremlin political elite, the "practical geopolitics." Consequently, the "popular geopolitics" was a main distributor and reflector of Moscow's entire negative geopolitical discourse towards Kosovo and the sponsor of its independence - the NATO Alliance.

For instance, the newspaper Kommersant in February 2008 covered 54 stories about the independence of Kosovo. Mostly all stories, which were more informative than biased, were related to the official reaction of Moscow. ${ }^{115}$ Many articles analyze the strong response of the Russian government, the President and Russian diplomats. Kommersant often emphasized the active role of President Vladimir Putin, who appears as the leader uniting CIS and the symbol of the Russian "practical geopolitics." "116 However, there were also other political personalities, Dmitry Rogozin, who was appointed as the Russian Ambassador to NATO, was presented as having a more rigorous personality than Vladimir Putin or Dmitry Medvedev. Dmitry Rogozin's lexicon was shown as rude and strident. He blamed NATO for expansionism, imperialism and funding Kosovo's drug lords. ${ }^{117}$ If outside observers recognized the inactive role of the Russians towards Kosovo's independence, then residents of the Russian Federation were sure their government struggled against NATO as Russian media was presenting it in the best possible light.

In contrast to Kommersant, Izvestia, the official Russian news agency, during the same period covered 160 stories about Kosovo's independence, which was threefold more than Kommersant had published. In addition, when Kosovo declared its unilateral independence, on the same day Izvestia published 20 stories which were more polemical rather than informative news. Izvestia claimed that Kosovo did not have a future, it would not achieve full freedom and once Kosovars had the opportunity, thousands of them would flee to Western Europe. ${ }^{118}$ In another article, Izvestia quoted an “emotional Vladimir Putin, who was ashamed of Europeans'

\footnotetext{
${ }^{115}$ In articles Kommersant.ru interviews different officials, diplomats and politicians. It pays lots of attention to the consequences of the Kosovo's precedent.

116 Владимир Соловьев, “Президент и провожающие его лица”, Kommersant.ru, February 22, 2008; Source: http://www.kommersant.ru/doc/855848?isSearch=True (accessed March 11, 2014).

117 Kommersan.ru, “Посол России в НАТО обвинил ЕС в связи с наркомафией”, February 26, 2008; Source: http://www.kommersant.ru/doc/856761?isSearch=True (accessed March 11, 2014).

${ }_{118}$ Izvestia.ru, “ Независимость Косово не решит проблемы населения края - эксперт”, February 17, 2008; Source: http://izvestia.ru/news/418724 (accessed March 11, 2014).
} 
double standards." 119 Izvestia emerges as a more pro-government and pro-Serbian newspaper than merely an unbiased media outlet. Consequently, the certain agenda of the Russian "popular geopolitics" helped the ruling elite to set a particular geopolitical discourse which was nothing more than anti-western.

Russian politicians, specialists and the mass media intensively debated the consequences of Kosovo's declared independence (with regard to Kosovo-related issues, the Russian geopolitical discourse became centralized and simultaneously operationalizing). It was undoubtedly clear - Russia was looking for political measures to respond to this exceptional crisis. Tim Judah, the Economist expert on the Balkan affairs, believes that it "was the time to seek revenge on Western countries for what Russians perceive as their humiliation in the 1990s" and for the active unilateral role of NATO in European affairs. ${ }^{120}$ NATO's certain geopolitical discourse towards the independence of Kosovo provoked the hostility and changes in the Russian geopolitical discourse in Europe and the Caucasus. Moscow's rejection of Kosovo's independence is "framed within contested values and norms - the most baleful legacy of the disputes nearly a decade earlier during OAF." ${ }^{21}$ The Kosovo war in 1999 dates the beginning of the Kosovo crisis, and the declaration of independence as the end. Within almost a decade, NATO-Russia relations changed as a result of the Kosovo crisis, and Russia became more politically independent and hostile towards NATO's unilateral policies and military operations.

Moreover, the declaration of Kosovo independence divided the international community, including NATO itself, and in pro-Russian countries anti-NATO moods began to appear. Some could argue that Europe is entering into a new Cold War, where a division between different NATO and Russian geopolitical discourses has emerged. Disputes over Crimea and later on in Eastern Ukraine prove that Kosovo's case was a precedent interpreted differently by Russian and NATO's geopolitical discourses. And even though NATO's geopolitical discourse towards the independence of Kosovo was neutral, the entire Russian geopolitical discourse can be assessed as negative. NATO's strategy and political decisions influenced negatively relations with the Russian Federation. Russia’s experience of Kosovo has, consequently, reinforced the perception

119 Izvestia.ru, “Путин подвел итог восьми лет президентства”, February 14, 2008; Source: http://izvestia.ru/news/418566 (accessed March 11, 2014).

${ }^{120}$ Judah Tim, Kosovo: what everyone needs to know, Oxford University Press, USA (2008), 137.

${ }^{121}$ Derek Averre, "From Pristina to Tskhinvali: the legacy of Operation Allied Force in Russia's relations with the West”, International Affairs 85: 3 (2009), 591 
of mistrust towards NATO. ${ }^{122}$ With the pronounced change in its geopolitical discourse, Russia was ready to defend its positions in European affairs and oppose future NATO activities in Europe and the Caucasus.

\subsubsection{Afghanistan in crisis}

In February 2000 the new Russian President Vladimir Putin thawed NATO-Russia relations which after the Kosovo war in 1999 were frozen for three months. The events of September 11 signaled to the Russian politicians and strategic community (practical and formal geopolitics) how far terrorism could extend and even threaten such a power as the U.S. Additionally, Moscow was deeply concerned about its own separatist regions and expanding global terrorism; consequently, it started to cultivate more pragmatic relations with NATO and its main sponsor - the United States.

On September 19, 2001 in an interview with the German ARD Television company, Putin strongly emphasized that "the response to the aggression with which the United States has been confronted must be prompt." ${ }^{, 123}$ From the outset Russia clearly stated its discourse towards the threat of terrorism. In the immediate aftermath of the 9/11 events, Putin even raised the question of possible Russian membership in NATO. ${ }^{124}$ Moscow was ready to cooperate with NATO in all feasible diplomatic and practical measures.

Besides the menace of terrorism, drug trafficking was another concern that led to Russian cooperation with NATO. At that time Afghanistan was a leading producer of poppies used for making heroin and supplied $80 \%$ of the global market. In his speech to the Security Council of the Russian Federation, Vladimir Putin emphasized that a fundamental task was "connected with the elimination of financial channels for narco-business, which can be cut off not only by fighting against criminal elements, but also through the use of a whole system of special measures." 125 For years Russia was not able to succeed in fighting against illegal drug

\footnotetext{
122 James Hughes, "Russia and the Secession of Kosovo: Power, Norms and the Failure of Multilateralism", EuropeAsia Studies Vol. 65, No. 5, July 2013, 1013

${ }^{123}$ Ministry of the Foreign Affairs of the Russian Federation, "Russian President Vladimir Putin Interview to German ARD Television Company", September 19, 2001; http://www.mid.ru/BDOMP/Brp_4.nsf/arh/0C81589342F914BF43256AD20041B18E?OpenDocument (accessed March 12, 2014).

${ }^{124}$ Martin A. Smith, "NATO-Russia relations: will the future resemble the past?", in NATO in search of a vision, ed. Gulner Aybet and Rebecca R Moore, Georgetown University Press (2010), 108-109.

${ }^{125}$ Ministry of the Foreign Affairs of the Russian Federation, "Speech by President Vladimir Putin at a Meeting of the Security Council of the Russian Federation”, September 28, 2001; Source:
} 
trafficking. Moscow was sure that cooperation with NATO could solve more problems than just terrorism.

If in 1999 the Russian geopolitical discourse towards the crisis in Kosovo and NATO was very negative, then after several years we can observe significant changes. First of all, the general structure of the Russian geopolitical culture (see page 17) was shaped by changes in the state apparatus (new political leaders appeared) and relations with neighbors (Russia was still economically and politically weak, thus pragmatism was necessary). Secondly, the Russian geopolitical tradition towards Asia was impacted by the growing threat of terrorism in Afghanistan and Pakistan. Consequently, these elements influenced the Russian geopolitical discourse towards the crisis in Afghanistan.

For the next few years NATO-Russian relations in regard to the Afghanistan crisis became even tighter. In May 2002 at the Russia-NATO Permanent Joint Council Meeting, Russia agreed to "strengthen cooperation through a multi-faceted approach, including joint assessment of the terrorist threat to the Euro-Atlantic area, focused on specific threats, for example, to Russian and NATO forces, to civilian aircraft, or to critical infrastructure." ${ }^{126}$ After the Rome summit in May 2002 the reciprocal cooperation was improved by the creation of the NATO-Russia Council in which Russia received co-decision responsibilities in "military crisis management, counterterrorism, non-proliferation of Weapons of Mass Destruction (WMD).”"127 In 2003 both sides agreed to deepen cooperation in ensuring security in Afghanistan and continue ongoing discussions at the NATO-Russia Council. In addition, Russia offered "to provide practical support to the NATO-led International Security Assistance Force (ISAF) in Afghanistan." "28 Regarding the war in Afghanistan, Russia mostly contributed to the Turkmenistan-Afghanistan border control, transit routes which pass through Russia (see Appendix Nr. 6), and bilateral training on practical aspects of the fight against terrorism.

http://www.mid.ru/BDOMP/Brp 4.nsf/arh/4CD8339743F900EE43256AD90039004D?OpenDocument $\quad$ (accessed March 12, 2014).

${ }^{126}$ Ministry of the Foreign Affairs of the Russian Federation, "Russia-NATO Permanent Joint Council Meeting at the Level of Foreign Ministers Held in Reykjavik" May 14, 2002; Source: http://www.mid.ru/BDOMP/Brp_4.nsf/arh/8E21ADD26AF395F843256BBA0034B640?OpenDocument (accessed March 12, 2014).

${ }^{127}$ Martin A. Smith, "NATO-Russia relations: will the future resemble the past?", in NATO in search of a vision, ed. Gulner Aybet and Rebecca R Moore, Georgetown University Press (2010), 110.

${ }^{128}$ Ministry of the Foreign Affairs of the Russian Federation, "Meeting Of The NATO-Russia Council At The Level Of Foreign Ministers NATO HQ, Thursday, 4 December 2003, Statement”, December 5, 2003; Source: http://www.mid.ru/BDOMP/Brp 4.nsf/arh/2025FD4144F00CAF43256DF30032757C?OpenDocument (accessed March 12, 2014). 
Putin's decision to support NATO in the struggle against terrorism and his redefinition of national interests led to an important change in the Russian geopolitical discourse. ${ }^{129}$ Cooperation with NATO in dealing with Afghanistan's problems and threat of terrorism allowed the Russian Federation to return to the international arena and participate in the decision-making process and implementation. Ultimately, Russia normalized its relations with NATO and helped to stabilize Afghanistan. Concerning the critical geopolitical approach, such a development of NATO-Russian relations could be explained by the geopolitical discourses of both sides, which were compatible. One could argue that both NATO and Russia have scripted the Afghanistan crisis in the same way - positively, thus it led to reciprocal cooperation.

Furthermore, as was already observed, due to Russian geopolitical culture in the larger sense, the media that represents the "popular geopolitics" had a close nexus with the "practical and formal geopolitics." It could be observed in all cases, but especially in recent ones, when the "practical geopolitics" usurped the "popular geopolitics," which eventually started to serve (but not influence) for the entire geopolitical discourse. As a result, the Russian government was also supported by the country's media which was influenced by the 9/11 attacks. Phenomena comparable to the western media could be observed in the Russian newspapers as well. NATO's and the Russian "popular geopolitics" were shaped by both the threat of terrorism and the other geopolitical elements (practical and formal geopolitics). However, in NATO's case, the media was not as influenced by the "practical geopolitics" as in Russia.

Nevertheless, the September 11 events fueled debates about terrorism which were already part of the Russian media's agenda since the second Chechnya war in late 1999. In a three-month period (September 11 - December 11, 2001), for instance, the newspaper Kommersant published 1000 stories related to terrorism, out of which 323 covered terrorism in Afghanistan, tenfold more than at the same time one year earlier. Other newspapers, particularly those with close tie to the Kremlin, backed up the politicians and daily reported their speeches, interviews and decisions regarding terrorism issues. The Russian "popular geopolitics" towards the Afghanistan crisis and NATO switched from negative post-Kosovo coverage to the positive post-9/11 coverage. ${ }^{130}$ For instance, according to the newspaper Lenta, the events of September 11 restored

\footnotetext{
129 Tsygankov, Andrei P., Russia's Foreign Policy: Change and Continuity in National Identity, (3rd Edition), Rowman \& Littlefield Publishers, (2010), 168.

${ }_{130}$ Lenta.ru, "Россия и НАТО будут вместе ловить организаторов терактов в США", September 13, 2001; Source: http://lenta.ru/world/2001/09/13/sammit/ (accessed March 13, 2014).
} 
negotiations on the establishment of a NATO mission in Moscow. ${ }^{131}$ There were also some articles criticizing the U.S. for its strict policy of those 'who are not with us are against us' towards the Afghanistan crisis. ${ }^{132}$

Nevertheless, several negative reports from the media did not influence Russian foreign policy and Moscow decided to join the campaign against terrorist groups in Afghanistan. It once again illustrates the "popular geopolitics" dependence on the Russian "practical geopolitics," which basically was the key element determining the entire Russian geopolitical discourse towards the Afghanistan crisis. Eventually, the expansion of warfare in Afghanistan propelled reciprocal cooperation between NATO and Russia, thus the overall Russian geopolitical discourse could be scripted the same as NATO - positive. Hence, we can argue that the same geopolitical discourse towards the crisis led to a natural cooperation. Russia was deeply concerned about global developments, thereby in May 2003 Russia and the rest Collective Security Treaty Organization (CSTO) member states established special institutions for fighting terrorism. Russia's same geopolitical discourse led to the reflection and duplication of NATO "practical and formal geopolitics," when Russia sought to create similar institutions to those already possessed by NATO.

However, since the inception of the Afghanistan crisis in 2001, Russian geopolitical discourse towards Afghanistan has changed as well. Despite the fact that NATO constantly seeks accommodation with Moscow regarding Afghanistan, Russia with its "current nationalistic and assertive mood, and with its opposition to core NATO policies, may not desire a truly cooperative partnership." 133 One the one hand, it illustrates how the entire geopolitical culture could influence other international actors (changes in the Russian status apparatus, identity, etc. also shaped NATO's geopolitical discourse), on the other hand it also presents that a single fixed event/issue does not determine the geopolitical discourse in contemporary Afghanistan. Thus, the Russian geopolitical discourse was also shaped by the previous military crises in Kosovo and Libya.

\footnotetext{
131 Lenta.ru, “Америка обошлась с Европой по-мусульмански”, Мay 29, 2002; Source: http://lenta.ru/articles/2002/05/28/nato/ (accessed March 13, 2014).

132 Леонид Ганкин, “С кем вы, мастера войны?”, Kommerstant.ru, September 19, 2001; Source: http://www.kommersant.ru/doc/283443?isSearch=True (accessed March 13, 2014);

${ }_{133}$ Jamie Shea, "NATO at sixty - and beyond", in NATO in search of a vision, ed. Gulner Aybet and Rebecca R Moore, Georgetown University Press (2010), 25.
} 
Professor Boris Barkanov believes that Russia has mixed feelings towards contemporary Afghanistan: "On the one hand, Russia is concerned about security in Afghanistan and Islamic fundamentalism." ${ }^{\prime 134}$ Afghanistan is situated next to the Central Asia region which is a traditional Russian sphere of interest. Consequently Russia has always been deeply concerned about the situation on the ground in Afghanistan. Historical experiences, regional interests and geographic range naturally influence the Russian geopolitical tradition and its geopolitical discourse towards Afghanistan. During the interview, the Senior Counselor Denis Gonchar from the Russian Embassy in Washington D.C., acknowledged that the situation in Afghanistan is disturbing and destabilizing the whole region. Besides, "Russia [has] concerns about the huge flow of drugs from Afghanistan to Central Asia and Russia; Terrorism is another problem that makes us [the Russians] to worry." 135

Despite mutual disputes and different geopolitical discourses in Europe, since 2010 Russia has provided non-military support to NATO's mission in Afghanistan. ${ }^{136}$ However, Russia's cooperation with NATO is based only on pragmatic interests. A major factor in Russian geopolitical discourse is Afghanistan's role as a producer and exporter of opium. Currently Russia wants to see ISAF working "on drugs issues, natural disasters and invest more money to the Afghanistan security." 137 Nevertheless, ISAF has chosen a policy of least resistance on opium growing, because it could drive indigenous Afghanis to an armed resistance against the remaining NATO troops in Afghanistan. Consequently, such a decision has influenced the Russian geopolitical discourse, which otherwise colludes with NATO's geopolitical discourse in Afghanistan. Thus Russia seeks to further strengthen international efforts under the auspices of the UN aimed at helping Afghanistan and its neighboring states to meet these challenges. ${ }^{138}$ Hence, the same issues gravitates Russia to cooperation and more pragmatic geopolitical discourse with NATO.

\footnotetext{
${ }^{134}$ Appendix 5, Interview Nr. 4.

${ }^{135}$ Appendix 2, Interview Nr. 1.

${ }^{136}$ Ukrainian orange revolution 2004; NATO's enlargement to the East Europe 2004; NATO's close cooperation with Ukraine and Georgia 2006-2008 and so on;

Supply route through Russian territory for ISAF; Counter-narcotics training of Afghan and Central Asian personnel and similar ways.

${ }^{137}$ Appendix 2, Interview Nr. 1.

${ }^{138}$ Ministry of the Foreign Affairs of the Russian Federation, "Concept of the Foreign Policy of the Russian Federation", February 2013; Source: http://www.mid.ru/bdomp/nsosndoc.nsf/1e5f0de28fe77fdcc32575d900298676/869c9d2b87ad8014c32575d9002b1c38!OpenDocument (accessed March 31, 2014).
} 
"On the other hand, they [the Russians] are not happy about a long term American presence in Afghanistan." ${ }^{" 139}$ Russia seeks to promote CSTO's role as the key partner for NATO in developing a regional approach towards Afghanistan. These divisions and rivalries might intensify after 2014, as Russia together with other Central Asian countries seek to restore and strengthen close ties with ethnic Tajik and Uzbek warlords. ${ }^{140}$ Eventually, Russia could try to stop the potential expansion of the Taliban's activities towards Central Asian borders after the NATO troops withdraw from Afghanistan after 2014.

Currently Russia is working on two geopolitical discourses towards Afghanistan and NATO's presence there. First of all, Moscow does not fully reject the presence of NATO forces in Afghanistan. If CSTO together with Russia might secure the external borders of Afghanistan, then NATO could still monitor internal security, but with one obligation - the forthcoming ISAF mission must be based on a UN SC resolution and UN mandate. And secondly, both Russia and even China have attempted to get guarantees from Afghanistan's government that NATO, especially the U.S., does not establish a long-term military presence in Central Asia as "a prerequisite for their input into the region-led stabilization programme." ${ }^{\text {"141 }}$ Such a dichotomy in the Russian geopolitical discourse could be explained by the uncertainty in contemporary Afghanistan. The Russian "practical and formal" geopolitics are tending to wait until the end of the year 2014.

However, in light of the Russian "popular geopolitics", it is more likely that the second case might appear as the most acceptable. Already in December 2013 Kommersant announced that "following the discussion [between NATO's and Russian representatives], it became clear that the parties fundamentally disagree on projections about what awaits Afghanistan after the withdrawal of the main body of the foreign contingent in 2014." ${ }^{142}$ Moreover, Kommersant also notices the pessimistic Russian geopolitical discourse towards Afghanistan after the withdrawal of NATO forces. Russian officials believe that contemporary Afghanistan soon will face unstable scenarios: "the return of the Taliban to power, a civil war, or the division of spheres of

\footnotetext{
139 Appendix 5, Interview Nr. 4.

${ }^{140}$ Oksana Antonenko, "The Central Asian states and Russia”, in Afghanistan to 2015 and beyond, ed. Toby Dodge and Nicholas Redman, Routledge (2011), 215-216.

${ }^{141}$ Ibid, 217.

142 Елена Черненко, “Россия и НАТО разошлись на афганском направлении”, Kommerstant.ru, December 16, 2013; Source: http://www.kommersant.ru/doc/2369414?isSearch=True (accessed March 15, 2014).
} 
influence between the Taliban and the current regime." ${ }^{143}$ A similar opinion could be also observed in other Russian newspapers such as Izvestia, Lenta or Pravda which constantly reflect Moscow's "formal and practical" geopolitics towards contemporary Afghanistan. Regarding the past experiences in Afghanistan and contemporary issues with NATO in Europe (the Ukrainian crisis), it is uncertain that Russia will seek to stabilize potential future threats in Central Asia or expand its political influence inside Afghanistan after the 2014 withdrawal of ISAF.

Consequently, the overall Russian geopolitical discourse in contemporary Afghanistan could be described as - neutral. Russia depends on NATO's activities and the influence of its geopolitical discourse in contemporary Afghanistan. At the same time, however, contemporary issues in Europe complicate the Russian geopolitical discourse towards Afghanistan. Moreover, knowing that NATO's geopolitical discourse toward the contemporary situation in Afghanistan is being increasingly scripted as negative, mutual cooperation between both sides as occurred at the beginning of the Afghanistan crisis in 2001 is unlikely in the future.

\subsubsection{The Libyan crisis}

Last, but not least, the crisis in Libya is NATO's final military operation that will be analyzed in this research. When in March 2011, NATO launched an air strike campaign against the Gaddafi regime, several particular features in the Russian geopolitical discourse towards the Libyan crisis emerged.

On the one hand, Russia's "formal geopolitics" constantly accused and blamed NATO of overstepping UN SC resolution 1973 and launching air strikes against Libya. A few days after NATO began Operation Unified Protector, the Ministry of Foreign Affairs of the Russian Federation issued a press-release in which Russia "strongly believes that it is unacceptable to use the mandate derived from UN SC resolution 1973, the adoption of which was quite an ambiguous step, in order to achieve goals that go far beyond its provisions, which only provide for actions for the protection of civilians." ${ }^{144}$ Besides, as was already mentioned regarding the French military supplies to the insurgents, Russia criticized NATO for violating UN SC resolution 1970 which was intended to impose an arms embargo on Libya.

\footnotetext{
143 Елена Черненко, “Прогнозы по Афганистану все более пессимистичны”, Kommerstant.ru, December 10, 2014; Source: http://www.kommersant.ru/doc/2364112?isSearch=True (accessed March 15, 2014).

${ }^{144}$ Ministry of the Foreign Affairs of the Russian Federation, "Statement by Russian MFA Spokesman Alexander Lukashevich on the Situation around Libya”, March 20, 2011; Source: http://www.mid.ru/BDOMP/Brp 4.nsf/arh/22D9B158DCC67AEFC325785B003366B2?OpenDocument (accessed March 24, 2014).
} 
Nevertheless, the Russian "formal and practical geopolitics" sought to become a mediator in the Libyan crisis and together with NATO join a campaign to implement the UN SC resolution. However, NATO's "formal and practical geopolitics" were orientated toward a unilateral decision to solve this crisis with air strikes, thus the Russian geopolitical discourse was not acceptable for NATO. ${ }^{145}$ One month after NATO launched the air strike campaign, Russia was still not accepted into "the UN SC resolution 1973 club" where only NATO and its partners were participating in the intensive bombing campaign. Russia was seeking to resolve this conflict peacefully, not because Russia was deeply concerned about the civilian casualties and human rights, which are not always recognized in Russia, but because of pragmatic reasons. A few years before the Arab Spring, Russia agreed with the Gaddafi regime to sign a bilateral economic agreement where Russia would cancel all Libyan debt in return for the possibility of Russian business companies to develop the Libyan civilian infrastructure and build railroads, factories, etc.

Thus Russian "formal and practical geopolitics" initially sought cooperation with NATO due to the expectations that it might lead Russia into the "club" of the international community, which governs the international order. Eventually, the rejections from NATO's side caused the counter-reaction from the Russian geopolitical discourse, which became negative.

Further, Vladimir Putin, the key figure of the Russian "practical geopolitics", appeared as a sharp critic of NATO activities in Libya. The "popular geopolitics" quoted his official statements and in comparison with the "practical geopolitics" (the official statements), were even more rigorous. Vladimir Putin harshly condemned the NATO air strikes on Libya; he argued that no one has the right to punish Moammar Gaddafi without trial; that the country's whole infrastructure was being destroyed, and in essence one of the warring sides was attacking the other under the cover of aircraft. ${ }^{146}$ Vladimir Putin was only one of the Russian officials who criticized NATO so strongly and more often than, for instance, Dimitri Medvedev, President of

\footnotetext{
${ }^{145}$ Ministry of the Foreign Affairs of the Russian Federation, "Russian Foreign Ministry Spokesman Alexander Lukashevich's Response to a Media Question about the Situation Surrounding Libya", April 4, 2011; Source: http://www.mid.ru/BDOMP/Brp_4.nsf/arh/2EF62115FCAC17F1C325786900369774?OpenDocument (accessed March 24, 2014).

146 Gleb Bryanski, "Putin: Libya coalition has no right to kill Gaddafi", Reuters, April 26, 2011; Source: http://www.reuters.com/article/2011/04/26/us-russia-putin-libya-idUSTRE73P4L920110426 (accessed March 24, 2014).

Kommersant.ru, “Ливия попросила Россию защитить от НАTO”, April 27, 2011; Source: http://www.kommersant.ru/doc/1629825? isSearch=True (accessed March 24, 2014).
} 
Russia at that time. It ones again shows that despite the different crises, the Russian geopolitical discourses are synchronized with each other, especially the "popular geopolitics," which does not influence the entire geopolitical discourse, but merely serve as the reflection of the Russian "practical geopolitics."

On the other hand, the Russian geopolitical discourse about Libya was not prioritized, because according to the Senior Counselor Denis Gonchar from the Russian Embassy in Washington D.C., "Libya it is not so strategically important to Russia." ${ }^{147}$ In addition, Russia was more concerned about the UN Security Council than Libya itself, "because no one cooperated with them (the Russians) in UN SC." ${ }^{148}$ Unilateral geopolitical decisions of NATO and solo implementation of the UN SC resolution 1973 once again excluded Russia from crisis management and cooperation. Others argue that Dimitri Medvedev simply did not care as much about Libya and consequently had some disputes with Vladimir Putin. Ultimately, Russia saw this conflict in terms of its impact on NATO, when involvement of the Alliance in another Arab country could increase anti-NATO, anti-American sentiments and weaken NATO's military capabilities during the economic crisis. As a result, Russia could increase its geopolitical discourse towards the European NATO member states, and eventually strengthen its pro-Arab diplomacy.

Overall, Russia was influenced by NATO's geopolitical discourse towards crisis in Libya. Undoubtedly, the Russian geopolitical discourse could be emphasized as negative. The independence of Kosovo and NATO's ongoing unilateral decisions in the international arena became a challenge for Russia. Different NATO and Russian geopolitical discourses towards the same crisis suggest that both parties tend to act in rivalry than in cooperation with each other. For instance, after the Libyan crisis, Russia tried to oppose other NATO unilateral decisions in Syria, which appeared as the potential 'Libya 2' scenario. For a certain time, Syria became the land of a proxy war, where Russia was supporting the Syrian government and NATO was sponsoring the opposition groups.

This chapter reviewed and analyzed how NATO and Russia scripted crises in Kosovo, Libya and Afghanistan and how it led to reciprocal accruing disagreements and, to a lesser extent, cooperation.

\footnotetext{
${ }^{147}$ Appendix 2, Interview Nr. 1.

148 Appendix 5, Interview Nr. 4.
} 


\section{The Interaction of Geopolitical Discourses}

We must recall that for the most part of this research we have not been looking at fixed outcomes of events, but rather at ongoing processes. This research suggests that attention to long lasting processes could help to comprehend how international actors create and recreate regional or global politics and how their different geopolitical discourses of crises have led to reciprocal accruing disagreements or, in some instances, cooperation (at this research between NATO and Russia shows). The previous sub-chapter briefly presented the changes in the international order which have been influenced by certain NATO and Russian geopolitical discourses. The table below recapitulates evaluations of NATO's and Russia's geopolitical discourses towards the Kosovo, Libya and Afghanistan crises in the previous 15 years. It provides an opportunity to look at NATO's military operations and realize how it shaped relations with the Russian Federation.

Table Nr. 5 NATO's and the Russian geopolitical discourses towards crises

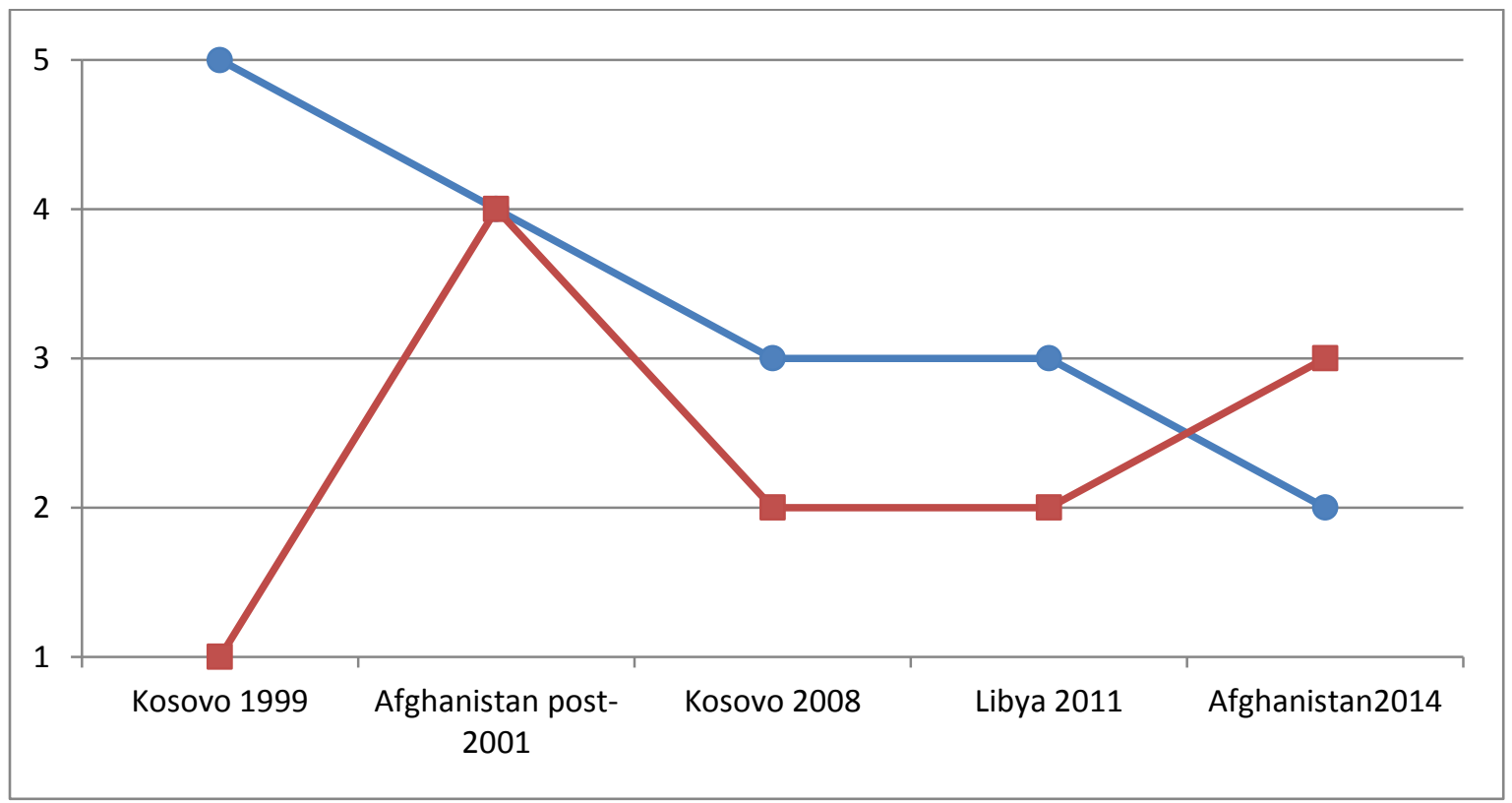

Source: made by the author regarding research. Discourse towards crises:

5 - very positive; 4 - positive, 3 - neutral; 2 - negative, 1 - very negative.

Red color - Russia; Blue color - NATO;

With respect to NATO's geopolitical discourse there have been several significant changes regarding these crises. After the Cold War NATO expanded military operations beyond its borders and as a result in the last 15 years NATO has participated in conflicts on three 
different continents, first in its natural sphere of interest - Europe, then in Africa and Asia. However, this research suggests that according to geopolitical discourses the performance of NATO forces has been gradually decreasing and there are growing debates about NATO's role as a global policeman or successful crisis manager.

In the last 15 years NATO defense spending has been gradually reduced. Consequently, the military capabilities of the Alliance steadily decreased as well. Additionally, NATO's operation in Afghanistan has absorbed a large proportion of the Allies' capabilities for more than a decade. ${ }^{149}$ The Brookings Institute, in its annual report, suggests that if "the defense spending continues to decline, NATO may not be able to replicate its success in Libya in another decade." ${ }^{\prime 50}$ At this moment only three out of 28 NATO member states satisfy a requirement of $2 \%$ GDP spending for defense. Reduction of military spending was one of the reasons why the success of the crisis resolution shifted from very positive (Kosovo) to neutral (Libya) and ultimately to negative (contemporary Afghanistan).

In addition, the deficiency of political consensus within NATO (lack of cooperation in the "practical" geopolitics) was another essential reason that undermined the effectiveness of NATO as a political structure. Though NATO's command and control (the "formal geopolitics") was working effectively during crises, however, in terms of the political decisions the division between the coalition of the willing (mostly the US or France with the UK) and the rest of NATO member states has constantly increased. Ultimately, at home, dissatisfaction within societies of NATO member states was gradually rising towards performance in overseas missions. The "popular geopolitics" did not serve in NATO's interest, in comparison with Russian geopolitical discourses. At particular moments in these crises NATO's "popular geopolitics" did not always reflect "formal and practical geopolitics", and more often criticized and opposed them. For instance, in 2013 The German Marshall Fund of the United States did a survey which found that in mostly all NATO member states the disapproval of a NATO intervention in Syria was more than $60 \% .{ }^{151}$ NATO's dubious victory in Libya and the long-

149 NATO official website, "Secretary General's Annual Report 2012"; Source: http://www.nato.int/cps/en/natolive/opinions_94220.htm (accessed March 30, 2014).

${ }^{150}$ Clara Marina O'Donnell, "The Implications of Military Spending Cuts for NATO's Largest Members", Brookings (July 2012); Source: http://www.brookings.edu/research/papers/2012/07/military-spending-nato-odonnell (accessed March 30, 2014).

151 The German Marshall Fund of the United States, "Transatlantic Trends survey 2013"; Source: http://trends.gmfus.org/files/2013/09/TTrends-2013-Key-Findings-Report.pdf (accessed March 30, 2014). 
lasting war in Afghanistan suggest that similar future expeditions are questionable and unlikely to happen.

As was already mentioned in the theoretical part of this study (see page 18), regarding NATO's past historical events and new global severities, its geopolitical traditions could be distinguished as 'Euro-Atlantic collective defence' and 'crisis manager'. However, in the last 15 years, NATO's geopolitical tradition of 'crisis manager' has turned out as ineffective and eventually unsuccessful. More importantly, for the purposes of this study, NATO military interventions influenced its relations with the Russian Federation.

In the case of the Russian geopolitical discourses there were also some essential changes towards the three crises. If during the 1999 Kosovo crisis there was a zero-sum game, when the victory of NATO was the defeat of Russia, then after the 9/11 attacks Russia engaged in closer cooperation with NATO for the first time. On the one hand it was influenced by the new Russian geopolitical culture, which was shaped by the president Vladimir Putin, but on the other hand the threat of terrorism demanded more pragmatic relations between Russia and NATO.

Regarding the European issues, the independence of Kosovo marked a new shift in Russian geopolitical tradition towards Europe and cooperation with NATO. Kosovo's independence was the breaking point when relations between NATO and Russia started to change to more negative rather than positive. Before that, disputes between both sides were constantly increasing due to NATO's active enlargement and attempts to influence Ukraine and Georgia. Some could argue that, for instance, issues of contemporary Afghanistan are a political platform to improve cooperation between both sides. However, Russia is more neutral and pragmatic in this case. On the one hand NATO is leaving the Central Asian region and it provides an opportunity to expand Russian influence, but on the other hand the uncertainty of Afghanistan's future worries the Russian officials as well.

Undoubtedly, the interventions of NATO military forces in Kosovo, Afghanistan and Libya have affected Russian foreign and security policies after the Cold War. The dramatic events of September 2001 showed that in spite of the Kosovo war in 1999, Russia was ready to cooperate with the Alliance. The year 2002 was promising for both sides. Eventually, positive reciprocal geopolitical discourses led to the establishment of the NATO-Russia Council where decisions and actions were taken by joint agreements. However, NATO's unilateral decisions 
and specific geopolitical discourses towards these crises excluded Russia from crisis management in Afghanistan and especially in Kosovo, which at the beginning of 2008 declared its independence. The crisis of Kosovo in 2008 dates the end of the Russian flexible policy towards NATO and marks the new beginning of a permanently hostile policy (the geopolitical discourse) against NATO in Europe. This can be demonstrated by several examples.

First of all, despite the global economic crisis and the fall of oil prices in the period of 2008-2010, Russia still gradually increased its military spending from 66 billion dollars (2008) to 93 billion dollars (2013), now $40 \%$ more than in $2008 .^{152}$

Secondly, in order to create a counterbalance to NATO, Russia propelled negotiations within CSTO. Consequently, Moscow encouraged the creation of the Collective Rapid Reaction Force, which was established in 2009, and in 2010 CSTO approved the declaration establishing a CSTO peacekeeping force. Such attempts suggest that Russia seeks to duplicate NATO's activities, and eventually if Russia has an international peacekeeping force, it could have a legal basis to intervene in crises zones and unilaterally resolve conflicts, the same as NATO did in Kosovo, Libya, or Afghanistan.

Thirdly, different geopolitical discourses could also be revealed by Moscow's official position towards NATO. According to the Russian military doctrine from 2010, NATO is the main external threat to the Russian Federation. Furthermore, the research suggests that the Russian government subsidizes and controls the majority of media and press. Thus journals, television and newspapers often promote and reflect a certain geopolitical discourse that only serves the Kremlin's policy which is aimed against NATO.

Fourthly, the crises indicate that Europe became the fundamental sphere of interest where the Russian geopolitical tradition has shifted dramatically in the last 15 years. With less interest and opposition to NATO in other regions Russia concentrates its major resources towards European affairs, including the Caucasus region.

With regard to evidence for this thesis, the hypothesis that different NATO and Russian geopolitical discourses towards crises in Kosovo, Libya and Afghanistan have led to reciprocal disagreements is only partly satisfied. NATO military interventions in Kosovo, Libya and Afghanistan have negatively affected relations with Russia mostly in Europe. Mutual

152 Stockholm International Peace Research Institute, "SIPRI Military Expenditure Database"; Source: http://www.sipri.org/research/armaments/milex/milex_database (accessed March 31, 2014). 
cooperation and diplomatic disputes towards crises in Libya and Afghanistan are minor in comparison with the NATO-Russian relations on the European continent.

First of all, contemporary disputes in Ukraine prove that Russia is ready to defend its geopolitical tradition in Europe. Secondly, serious Russian geopolitical discourses of European affairs (disputes in Kosovo, Georgia, Crimea and Eastern Ukraine) suggest that the Russian geopolitical tradition towards Europe is fundamental in comparison with other geopolitical traditions (Eurasia or Russia as a bridge between East and West). Thirdly, NATO's geopolitical discourses with regard to crises led to reciprocal accruing disagreements than to cooperation (with only one exception in Afghanistan 2001, when reciprocal discourse was the same). And finally, Russian economic and military capabilities are too weak to oppose NATO's missions overseas. Thus Russia will concentrate most of its geopolitical attention on Europe. 


\section{Conclusions}

1. The critical geopolitics turns out as a critique of modern geopolitics. The critical geopolitics concentrates on both the relations between states and creation, approval and implementation of particular policies or decisions. Gearóid Ó Tuathail's and Simon Dalby's conceptualization of the critical geopolitics are used as the research method. Every state or agency consist of history, geography, identity, state apparatus and power networks, which determine certain geopolitical traditions. Russia's geopolitical traditions could be named as 'Russia within Europe', 'Eurasian theory', and 'Russia as a bridge between East and West' and NATO's geopolitical traditions as 'Euro-Atlantic collective defence' and 'crisis manager.' Every geopolitical tradition consists of several geopolitical discourses which are divided into: "formal geopolitics" (think tanks, strategy makers, etc.), "practical geopolitics" (decision makers, official statements, documents, strategies and speeches) and "popular geopolitics" (the discourse of the media and surveys). All three geopolitical discourses interact and influence each other, thus the lines between them could blur. This could be observed especially in the Russian case, when due to specific characteristics of Russia's geopolitical culture, elements of the geopolitical discourse becomes closely related, mostly controlled and monopolized by the "practical geopolitics." In the Alliance case, NATO's "formal and practical geopolitics" usually cooperate with each other, but the "popular geopolitics" often criticizes both of them. The combination of three critical geopolitics elements allows us to determine certain NATO and Russian geopolitical discourses towards crises in Kosovo, Libya and Afghanistan.

2. With regard to Kosovo crisis in 1999 NATO's geopolitical discourse stayed very positive, "practical and formal geopolitics" were strongly supported and partly influenced by the "popular geopolitics." In contrast to NATO Russia scripted this crisis as very negative. The active involvement of NATO's "formal and practical geopolitics" led to the limitations and hostility of the Russian decision and strategy makers.

In 2001, NATO's geopolitical discourse towards Afghanistan could be explained as positive. With the support from the "popular geopolitics", NATO strategy and decisions makers achieved only temporary success in Kabul and its surroundings. The same geopolitical discourse could be observed from the Russian side. The expansion of warfare in Afghanistan and the threat of terrorism propelled reciprocal cooperation between NATO and Russia. The compatible geopolitical discourse united both sides and increased mutual partnership. 
However, in 2008 due to lack of consensus within the Alliance, NATO's geopolitical discourse towards the independence of Kosovo appeared as neutral. The overall Russian geopolitical discourse turned out as negative. NATO's "formal and practical geopolitics" excluded Russia from the decision making and ignored the Russian geopolitical discourse towards European affairs. Consequently, the Russian geopolitical discourse became more hostile and the perception of mistrust towards NATO increased.

During the crisis in Libya, NATO's geopolitical discourse was scripted as neutral. Even though Gaddafi's regime was changed, internal disputes within NATO and criticism from "popular geopolitics" downgraded NATO's geopolitical discourse as a whole to neutral. In contrast to NATO, the Russian geopolitical discourse was negative. Similarly to the Kosovo crisis in 2008, Russia was excluded from the decision making in the international arena. NATO's rejection of the Russian geopolitical discourse towards the Libyan crisis provoked a counterreaction from Moscow.

Ultimately, in contemporary Afghanistan, due to the division within NATO and criticism from the media, the entirety of NATO's geopolitical discourse could be defined as negative. However, Russia's geopolitical discourse turns out as neutral. One the one hand, Russia is deeply concerned about NATO's issues in contemporary Afghanistan and the possible return of the Taliban, but on the other hand, due to contemporary disputes in Europe Russia does not seek to cooperate with NATO so closely as it did a decade ago.

3. According to geopolitical discourses the performance of NATO forces has been gradually decreasing and the future of NATO as a 'crisis manager' is debatable. Undoubtedly, NATO's geopolitical discourses influenced relations with Russia. However, the hypothesis of this research "Different NATO and Russian geopolitical discourses towards crises in Kosovo, Libya and Afghanistan have led to reciprocal accruing disagreements" is only partly correct. Russia does not have crucial interests in other world regions and is basically too weak to oppose NATO's activities around the globe. Thus Moscow concentrates its attention on its fundamental geopolitical tradition in Europe. 


\section{Bibliography}

\section{Books:}

1. Albrecht Shnabel and Ramesh Thakur, Kosovo and the challenge of humanitarian intervention: selective indignation, collective action, and international citizenship, United Nations University Press, 2000.

2. Alexandra Gheziu, NATO in the "New Europe": The Politics of International Socialization after the Cold War, Stanford University Press, 2005.

3. Alison Pargeter, Libya: The Rise and Fall of Qaddafi, Yale University Press, 2012.

4. Andreas Behnke, NATO's Security Discourse after the Cold War: Representing the West, Routledge; 1st edition, 2012.

5. Campbell Horace, Global NATO and the Catastrophic Failure in Libya, Monthly Review Press, 2013.

6. David S. Yost, NATO Transformed: The Alliance's New Roles in International Security, United States Institute of Peace Press, 1998.

7. Dodds Klaus, Global Geopolitics: A Critical Introduction, Routledge, 2004.

8. Gearóid Ó Tuathail and Simon Dalby, Introduction: Rethinking Geopolitics, Routledge; second edition, 2002.

9. Gearóid Ó Tuathail, Simon Dalby and P. Routledge, The Geopolitics Reader, Routledge, second edition, 2006.

10. Ivan Dinev Ivanov, Transforming NATO: New Allies, Missions and Capabilities, Rowman \& Littlefield Publishers, 2011.

11. Jamie Shea, "NATO at sixty - and beyond", in NATO in search of a vision, ed. Gulner Aybet and Rebecca R Moore, Georgetown University Press, 2010.

12. John Agnew, Geopolitics: Re-visioning World Politics, Routledge; 2nd edition, 2003.

13. John Norris, Collision course: NATO, Russia, and Kosovo, Praeger Press, 2005.

14. Judah Tim, Kosovo: what everyone needs to know, Oxford University Press, USA 2008.

15. Klaus Dodds, Merje Kuus and Joanne Sharp, The Ashgate Research Companion to Critical Geopolitics, Ashgate, 2013.

16. M. J. Williams, The Good War: NATO and the liberal conscience in Afghanistan, Palgrave Macmillan, 2011. 
17. Martin A. Smith, "NATO-Russia relations: will the future resemble the past?", in NATO in search of a vision, ed. Gulner Aybet and Rebecca R Moore, Georgetown University Press, 2010.

18. Oksana Antonenko, "The Central Asian states and Russia", in Afghanistan to 2015 and beyond, ed. Toby Dodge and Nicholas Redman, Routledge, 2011.

19. Sten Rynning, NATO in Afghanistan: The Liberal Disconnect, Stanford Security Studies (2012)

20. Tsygankov, Andrei P., Russia's Foreign Policy: Change and Continuity in National Identity, (3rd Edition), Rowman \& Littlefield Publishers, 2010.

21. Дмитрий Тренин and Екатерина Степанова, Косово: международные аспекты кризиса, Moscow Carnegie $\quad$ Center, 1999, Source: http://carnegieendowment.org/files/cosovomnaspekty.pdf

\section{$\underline{\text { Journal articles }}$}

22. Clara Marina O’Donnell, “The Implications of Military Spending Cuts for NATO’s Largest Members", Brookings (July 2012); Source: http://www.brookings.edu/research/papers/2012/07/military-spending-nato-odonnell

23. Derek Averre, "From Pristina to Tskhinvali: the legacy of Operation Allied Force in Russia's relations with the West", International Affairs 85: 3 (2009),

24. Eugeniusz Smolar, "Transatlantic relations and NATO”, European View 10:127-135, Centre for European Studies (2011).

25. Fouberg, Erin H., Alexander B. Murphy, and H. J. de Blij, Human Geography: People, Place, and Culture (10 ed.), (2012).

26. Gearóid Ó Tuathail and Simon Dalby, "Geopolitics and discourse: Practical geopolitical reasoning in American foreign policy", Political Geography Vol. 11, No. 2, March 1994).

27. Geir Ulfstein And Hege Føsund Christiansen, “The Legality Of The NATO Bombing In Libya", ICLQ vol. 62, (2013).

28. H. J. Mackinder, "The Geographical Pivot of History", The Geographical Journal, Vol. 23, No. 4 (Apr., 1904).

29. James Hughes, "Russia and the Secession of Kosovo: Power, Norms and the Failure of Multilateralism", Europe-Asia Studies Vol. 65, No. 5, (July 2013), 
30. S.B. Cohen, "Geopolitical realities and United States foreign policy", Political Geography 22 (2003).

31. Valerii Senderov, "Neo-Eurasianism: Realities, Dangers, Prospects", Russian Politics and Law, vol. 47, no. 1, (January-February 2009).

32. Vladimir Kozin, Five lessons from Kosovo's “independence", International Affairs Moscow 54: 4, (2008).

\section{Legal documents}

33. EU Commission's regulation "No 900/1999 prohibiting the sale and supply of petroleum and petroleum products to the Federal Republic of Yugoslavia"; Source: http://eurlex.europa.eu/LexUriServ/LexUriServ.do?uri=COM:1999:0455:FIN:EN:PDF

34. Ministry of the Foreign Affairs of the Russian Federation, "Concept of the Foreign Policy of the Russian Federation", February 2013; Source: http://www.mid.ru/bdomp/nsosndoc.nsf/1e5f0de28fe77fdcc32575d900298676/869c9d2b87ad8014c32575d9002b1c38!Op enDocument

35. NATO military strategy 2010: http://www.nato.int/nato_static/assets/pdf/pdf_publications/20120203_strategic-concept2010-eng.pdf

36. NATO strategic concept $1999 ; \quad$ Source: http://www.nato.int/cps/en/natolive/official_texts_27433.htm

37. Political and Military Objectives of NATO Action with regard to the crisis in Kosovo, March 23, 1999: http://www.nato.int/cps/en/natolive/official_texts_27451.htm?selectedLocale=en

38. Prague Summit Declaration Issued by the Heads of State and Government participating in the meeting of the North Atlantic Council in Prague on 21 November 2002; Source: http://www.nato.int/docu/pr/2002/p02-127e.htm

39. Russian military doctrine 2010: http://carnegieendowment.org/files/2010russia_military_doctrine.pdf

40. The Foreign Policy Concept Of The Russian Federation (2008); Source: http://archive.kremlin.ru/eng/text/docs/2008/07/204750.shtml

41. UN reports about Afghanistan; 2013: http://daccess-ddsny.un.org/doc/UNDOC/GEN/N13/571/98/PDF/N1357198.pdf?OpenElement and 2012: 
$\underline{\text { http://daccess-dds- }}$

ny.un.org/doc/UNDOC/GEN/N12/239/52/PDF/N1223952.pdf?OpenElement

42. UN SC resolution $1244 \quad$ (1999); Source: http://daccess-ddsny.un.org/doc/UNDOC/GEN/N99/172/89/PDF/N9917289.pdf?OpenElement

43. UN SC resolution Doc S/RES/1973 (March 17, 2011); Source: https://www.un.org/News/Press/docs/2011/sc10200.doc.htm

\section{Official statements}

44. Ministry of the Foreign Affairs of the Russian Federation, "Meeting Of The NATO-Russia Council At The Level Of Foreign Ministers NATO HQ, Thursday, 4 December 2003, Statement", December $\quad$ 5, 2003; Source: http://www.mid.ru/BDOMP/Brp_4.nsf/arh/2025FD4144F00CAF43256DF30032757C?Open Document

45. Ministry of the Foreign Affairs of the Russian Federation, "Russian President Vladimir Putin Interview to German ARD Television Company", September 19, 2001; Source: http://www.mid.ru/BDOMP/Brp_4.nsf/arh/0C81589342F914BF43256AD20041B18E?Open Document

46. Ministry of the Foreign Affairs of the Russian Federation, "Russia-NATO Permanent Joint Council Meeting at the Level of Foreign Ministers Held in Reykjavik" May 14, 2002; Source:

http://www.mid.ru/BDOMP/Brp_4.nsf/arh/8E21ADD26AF395F843256BBA0034B640?Ope $\underline{\text { nDocument }}$

47. Ministry of the Foreign Affairs of the Russian Federation, "Russian Foreign Ministry Spokesman Alexander Lukashevich's Response to a Media Question about the Situation Surrounding Libya", April 4, 2011; Source: http://www.mid.ru/BDOMP/Brp_4.nsf/arh/2EF62115FCAC17F1C325786900369774?Open Document

48. Ministry of the Foreign Affairs of the Russian Federation, "Speech by President Vladimir Putin at a Meeting of the Security Council of the Russian Federation", September 28, 2001; Source: 
http://www.mid.ru/BDOMP/Brp 4.nsf/arh/4CD8339743F900EE43256AD90039004D?Open

Document

49. Ministry of the Foreign Affairs of the Russian Federation, "Statement by Russian MFA Spokesman Alexander Lukashevich on the Situation around Libya", March 20, 2011; Source: http://www.mid.ru/BDOMP/Brp_4.nsf/arh/22D9B158DCC67AEFC325785B003366B2?Ope nDocument

50. NATO official website, "Secretary General's Annual Report 2012”; Source: http://www.nato.int/cps/en/natolive/opinions_94220.htm

51. NATO Press release, "Statement by the NATO Spokesman", September 13, 2001; Source: http://www.nato.int/DOCU/pr/2001/p01-125e.htm

52. NATO Press release, "Statement by the North Atlantic Council after Kosovo's declaration of independence", February 18, 2008; Source: http://www.nato.int/docu/pr/2008/p08-025e.html

53. NATO Press, "Statement to the Press by NATO Secretary General, Lord Robertson, on the North Atlantic Council Decision On Implementation Of Article 5 of the Washington Treaty following the 11 September Attacks against the United States", October 4, 2001; Source: http://www.nato.int/docu/speech/2001/s011004b.htm

54. NATO's role in Kosovo; Source: http://www.nato.int/cps/en/natolive/topics 48818.htm

55. Official website of NATO, "NATO and Afghanistan"; Source: http://www.nato.int/cps/en/natolive/topics_8189.htm

56. Press statement: meeting of the NATO-Russia Permanent Joint Council at Ambassadorial level (November 17, 1999); Source: http://www.nato.int/cps/en/natolive/official_texts_27413.htm?selectedLocale=en

57. Statement by the NATO-Russia Permanent Joint Council on the Security Situation in Kosovo (June 23, 1999); Source: http://www.nato.int/cps/en/natolive/official_texts_27424.htm?selectedLocale=en

58. Statement by the North Atlantic Council on Kosovo, January 30, 1999, http://www.nato.int/cps/en/natolive/official_texts_27459.htm?selectedLocale=en

59. Stockholm International Peace Research Institute, "SIPRI Military Expenditure Database"; Source: http://www.sipri.org/research/armaments/milex/milex_database

60. The German Marshall Fund of the United States, "Transatlantic Trends survey 2013"; Source: http://trends.gmfus.org/files/2013/09/TTrends-2013-Key-Findings-Report.pdf 
61. The official site of the Ministry of the Foreign Affairs of the Russian Federation, "Statement by Russia's Ministry of Foreign Affairs on Kosovo", February 17, 2008; Source: http://www.mid.ru/bdomp/brp_4.nsf/e78a48070f128a7b43256999005bcbb3/041c5af46913d3 $\underline{8 \mathrm{ac} 32573 \mathrm{f} 30027 \mathrm{~b} 380 \text { !OpenDocument }}$

62. UN News Center, "Civilian casualties in Afghanistan up 14 per cent last year, says new UN report", $\quad$ February $\quad$ 8, 2014; http://www.un.org/apps/news/story.asp/story.asp?NewsID=47107\&Cr=Afghan\&Cr1=\#.UyM $\underline{\text { wiT95Meg }}$

\section{Newspaper articles}

63. Alessio Vinci, "Analysis: Kosovo now and then", $C N N$ February 15, 2008, Source: http://www.cnn.com/2008/WORLD/europe/02/15/kosovo.vinci/index.html?iref=allsearch

64. BBC.co.uk, "Nato strikes: Week two", April 12, 1999, Source: http://news.bbc.co.uk/2/hi/special_report/1998/kosovo2/317324.stm

65. BBC.co.uk, "Recognition for new Kosovo grows", March, 18, 2008; Source: http://news.bbc.co.uk/2/hi/europe/7251359.stm

66. Charles Krauthammer, "The Clinton doctrine”, CNN, March 29, 1999 http://www.cnn.com/ALLPOLITICS/time/1999/03/29/doctrine.html

67. CNN.com, "Solana stresses NATO resolve in Kosovo conflict", May 4, 1999, Source: http://www.cnn.com/WORLD/europe/9905/04/kosovo.solana/

68. David S. Cloud, "NATO puts pressure on Afghanistan to sign troop agreement", Los Angeles Times, February 26, 2014; Source: http://www.latimes.com/world/worldnow/la-fg-wn-natoafghanistan-20140226,0,6307655.story\#axzz2vxFgISK3

69. Der Spiegel, "Debatte um Unabhängigkeit: USA erkennen Kosovo an - Deutschland und viele EU-Staaten wollen mitziehen", March 18, 2008; Source: http://www.spiegel.de/politik/ausland/debatte-um-unabhaengigkeit-usa-erkennen-kosovo-andeutschland-und-viele-eu-staaten-wollen-mitziehen-a-536051.html

70. Der Spiegel, "Pristina: Kosovo erklärt sich für unabhängig", March 17, 2008; Source: http://www.spiegel.de/politik/ausland/pristina-kosovo-erklaert-sich-fuer-unabhaengig-a$\underline{535810 . h t m l}$ 
71. Der Spiegel, "Reaktionen auf Kosovo-Unabhängigkeit: Europas neues Problemkind”, March 17, 2008; Source: http://www.spiegel.de/politik/ausland/reaktionen-auf-kosovounabhaengigkeit-europas-neues-problemkind-a-535852.html

72. Emma Graham-Harrison, "Relationship between Hamid Karzai and US grows ever more poisonous", The Guardian, January 28, 2014; Source: http://www.theguardian.com/world/2014/jan/29/relationship-hamid-karzai-us-afghanistan

73. Gleb Bryanski, "Putin: Libya coalition has no right to kill Gaddafi”, Reuters, April 26, 2011; Source: $\quad$ http://www.reuters.com/article/2011/04/26/us-russia-putin-libyaidUSTRE73P4L920110426

74. Ivo H. Daalder, "NATO, the UN, and the Use of Force", March 1999; Source: http://www.brookings.edu/research/papers/1999/03/globalgovernance-daalder

75. Izvestia.ru, “ Независимость Косово не решит проблемы населения края - эксперт”, February 17, 2008; Source: http://izvestia.ru/news/418724

76. Izvestia.ru, “Путин подвел итог восьми лет президентства”, February 14, 2008; Source: http://izvestia.ru/news/418566

77. Kommersan.ru, “Посол России в НАТО обвинил ЕС в связи с наркомафией”, February 26, 2008; Source: http://www.kommersant.ru/doc/856761?isSearch=True

78. Kommersant.ru, “Ливия попросила Россию защитить от НАTO”, April 27, 2011; Source: http://www.kommersant.ru/doc/1629825?isSearch=True

79. Kommerstant.ru, “Я теперь знаю, как бывает в аду”, March 26, 1999; Source: http://www.kommersant.ru/doc/215619?isSearch=True

80. Lenta.ru, “Америка обошлась с Европой по-мусульмански”, Мау 29, 2002; Source: http://lenta.ru/articles/2002/05/28/nato/

81. Lenta.ru, "Россия и НАТО будут вместе ловить организаторов терактов в США", September 13, 2001; Source: http://lenta.ru/world/2001/09/13/sammit

82. Oliver Rolofs, "A Breeze Of Cold War", MSC, February 2007; Source: https://www.securityconference.de/en/about/munich-moments/a-breeze-of-cold-war/

83. Pravda.ru, “ Представитель СРЮ обвиняет НАТО в сговоре с Армией освобождения Косово с целью усиления влияния Альянса на Балканах", April 1, 1999; Source: http://www.pravda.ru/news/world/01-04-1999/900472-0/ 
84. Pravda.ru, “ Сегодня представители блока левых сил Украины пикетировали посольство США”, March 25, 1999; Source: http://www.pravda.ru/news/world/25-031999/904126-0/

85. Pravda.ru, “Силовой Метод Решения Проблемы Косово Завел Нато В Тупик”, March 6, 1999; Source: http://www.pravda.ru/news/world/06-04-1999/900558-0/

86. Spiegel.de, "Fertiger Plan für den Bodenkrieg”, 26.04.1999, Source: http://www.spiegel.de/spiegel/print/d-12771283.html

87. The New York Times, "In Afghanistan, Protests Over Disposal of Korans", February 21, 2012; Source: http://www.nytimes.com/slideshow/2012/02/21/world/asia/20120222$\underline{\text { AFGHANISTAN.html?ref=northatlantictreatyorganization }}$

88. UN News Center, "Precarious security situation in Libya shows need for dialogue with militias - $\quad$ UN envoy”, $\quad$ December 9, 2013; $\quad$ Source: http://www.un.org/apps/news/story.asp//story.asp?NewsID=46696\&Cr=libya\&Cr1=\#.UzTD Zqh5Meg

89. Yalda Hakim, “Afghanistan's Hamid Karzai says NATO caused great suffering”, $B B C$, October 7, 2013; Source: http://www.bbc.com/news/world-24433433

90. Афанасий Сборов, “Милошевич раздражает многих”, March 26, 1999; Source: http://www.kommersant.ru/doc/215622?isSearch=True

91. Владимир Соловьев, “Президент и провожающие его лица”, Kommersant.ru, February 22, 2008; Source: http://www.kommersant.ru/doc/855848?isSearch=True

92. Геннадий Сысоев, “Война без правил”, April 6, 1999; Source: http://www.kommersant.ru/doc/15336?isSearch=True

93. Елена Черненко, “Прогнозы по Афганистану все более пессимистичны”, Kommerstant.ru, December $\quad$ 10, 2014; http://www.kommersant.ru/doc/2364112?isSearch=True

94. Елена Черненко, “Россия и НАТО разошлись на афганском направлении”, Kommerstant.ru, $\quad$ December $\quad 16, \quad 2013 ; \quad$ Source: http://www.kommersant.ru/doc/2369414?isSearch=True

95. Леонид Ганкин, “С кем вы, мастера войны?”, Kommerstant.ru, September 19, 2001; Source: http://www.kommersant.ru/doc/283443?isSearch=True 


\section{Appendix}

Appendix Nr. 1

Map Nr. 1. H. J. Mackinder's The World-Island and the Heartland

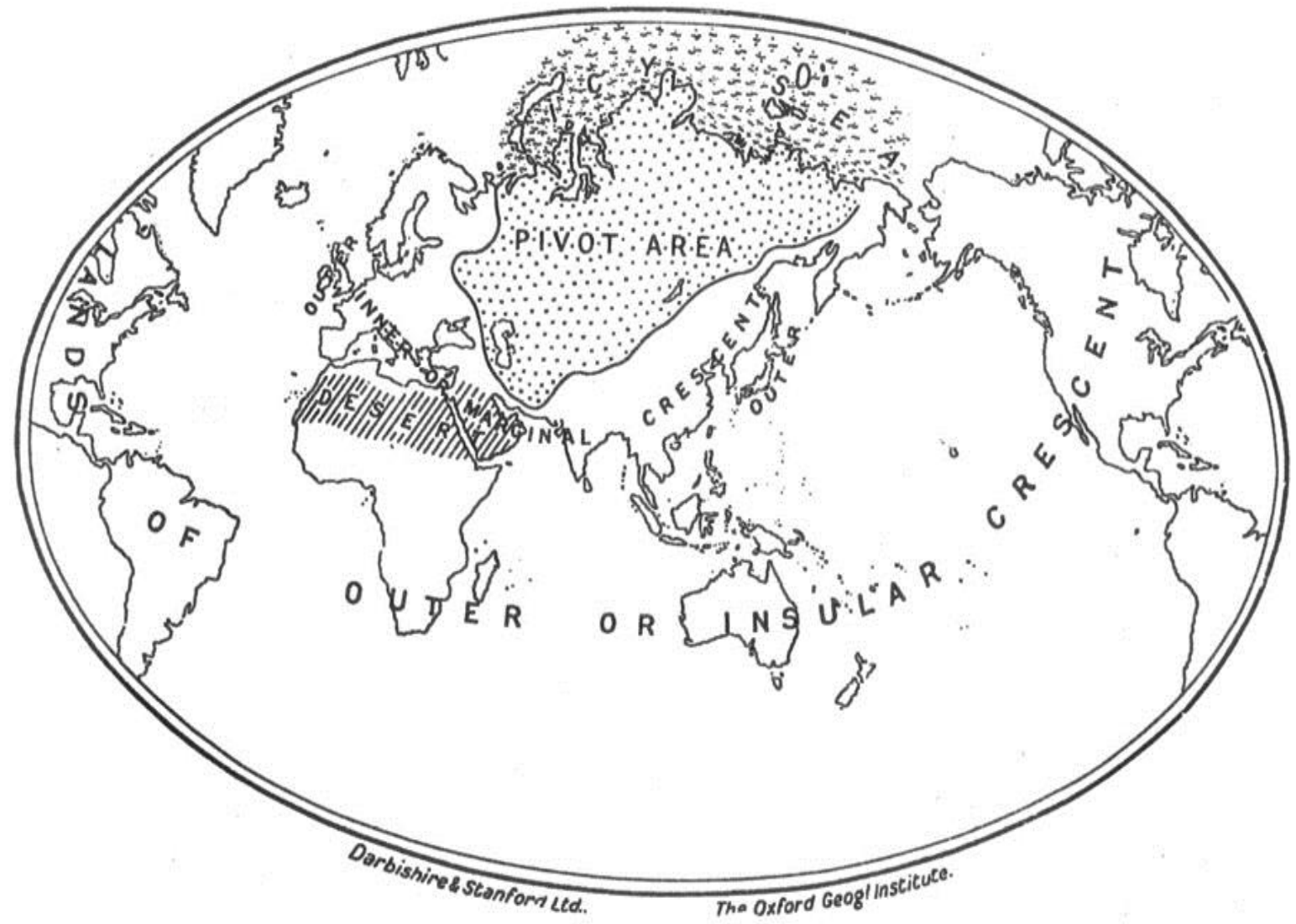

\section{Source:}

http://www.anselm.edu/academic/history/hdubrulle/WWII/WWII2010/text/grading/food/fdwk05 b.htm (accessed Feb 2, 2014) 
Appendix Nr. 2

Interview Nr. 1 Interview with the Senior Counselor Denis Gonchar and in the Russian Embassy in Washington D.C. (13.02.2014)

1. What were the Russian perception and discourse after NATO's invasion in Kosovo in 1999 ?

In 1999 the invasion of Kosovo was the biggest violation of law. NATO intervention violated international law towards Serbians and after bombing Serbia relations between Russia and NATO were frozen.

2. How have the Russian perception and discourse changed after 2008 Kosovo declaration of independence?

Russia still does not recognize an independence of Kosovo. However, we support dialogue between Serbia and Kosovo. There must be consensus between both sides and Russia is ready to support and mediate negotiations.

\section{What did it mean to the international community?}

The declaration of Kosovo independence has created a precedent when separatist regions can act and demand separate autonomies, so it means that they could destabilize the sovereign countries.

4. How have the Russian perception and discourse changed after NATO's invasion in Libya 2011?

Well, Libya it is not so strategically important to Russia. However, we believe that there was misinterpretation of NATO activities during the Libyan crisis, but more statements you could find in our official websites.

\section{What did it mean to the international community?}

It simply destabilized the region and the consequences could be observed even now.

6. What are the Russian perception and discourse in current Afghanistan?

Situation on the ground is disturbing and destabilized. Russia concerns about the huge float of drugs from Afghanistan to Central Asia and Russia. Terrorism is another problem that makes us to worry. We think that ISAF must work on drugs issues, natural disasters and invest more money to the Afghanistan security.

7. What does this case mean to international community? 
Withdraw of NATO ISAF will destabilize the entire region. However, we believe that ISAF must stay in Afghanistan, but under mandate of UN. Currently Russia and NATO cooperate together and ensure transparent and safe withdraw of NATO troops from Afghanistan. We believe that CSTO could work together with NATO, where NATO ensures internal stability in Afghanistan and CSTO external security in the region.

\section{Thank you for your answers.}


Appendix Nr. 3

Interview Nr. 2 Interview with Dr. Ieva Karpaviciute, a special Lithuanian attaché to NATO HQ

1. What were the Russian perception and discourse after NATO's invasion in Kosovo in 1999?

Have no information about it.

2. How have the Russian perception and discourse changed after 2008 Kosovo declaration of independence?

For Russia it was a useful precedent applied in Georgian case

3. What did it mean to the international community?

It is kind of precedent and also an important process for a security in the Balkan region.

4. How have the Russian perception and discourse changed after NATO's invasion in Libya 2011??

More it was important at UN SC than directly at NATO. RF and NATO did not cooperate in Libyan case.

5. What did it mean to the international community?

Libyan case for international community was important in context of Arab Spring processes as well as MENA regional security and stability.

6. What are the Russian perception and discourse in current Afghanistan?

It is good question for Russia, they know better about their perception. Important are historical memories for Russian Federation, plus RF is affected by flows of narcotics into the country from Afghanistan, as well as ISAF transit and other related issues.

7. What does this case mean to the international community?

War in Afghanistan was one of the most important (expensive, in terms of lives and expenses, and long-lasting) military operations worldwide.

Thank you for your answers. 
Appendix Nr. 4

Interview Nr. 3 Interview with the senior expert Vadim Volovoj from the Centre of Geopolitical Studies (02.03.2014)

1. What were the Russian perception and discourse after NATO's invasion in Kosovo in 1999?

In Yeltsin times Russia was weak strategically and it could not play important role in the international arena. And of course, Russia understood that they cannot give any strong response to NATO. Of course, Russia was against the invasion into the Serbia and the Russian troops entering to Pristina was a symbolic try to show that they are also important. In the end Russia was still weak and not able to rival against NATO, because of internal problems within its own territory.

2. How have the Russian perception and discourse changed after 2008 Kosovo declaration of independence?

At that time Russia was rather influential in international arena, but still Russia could not let itself to rival western countries seriously. The most important thing for Russia is "near abroad' and Kosovo was the periphery of Russian influence. Also, Serbian government was not so active to oppose Kosovo's independence, so Putin did not see interest to protect Serbia. But on the other hand, Russia send a clear message to the west, that if they tolerate independence of Kosovo than Russia has a full right to do the similar things with Abkhazia and South Ossetia.

\section{What did it mean to the international community?}

International community became divided. In general the independence of Kosovo was a question of the western countries prestige in the case of success of military intervention. The case of South Ossetia's independence, western countries did not recognize it proving that there is double standards.

\section{How have the Russian perception and discourse changed after NATO's invasion in}

\section{Libya 2011?}

Crisis of Libya became current Syria which clearly shows Russian perception in today's world. And maybe only the fact of Dimitri Medvedev was that Russia did not to the same what it does now in Syria. Then V. Putin was disappointed with D. Medvedev's decision and we could have seen some disagreements between them. Russia learned from the mistakes in Libya and Syria became of it reflection. 


\section{What did it mean to the international community?}

I would only say from realistic paradigm of international relations that when the interest of big states (the US, France and so on) are on the table, they act as they want and despite any international law or other factors. And Libya is example of it - when big states rule international politics with cynical interest and military power.

\section{What are the Russian perception and discourse in current Afghanistan?}

I would say that for this moment the main purpose of Russia in Afghanistan is stability, even though the US ensures now it. However, Russia is not happy knowing that the US is in the region for too long, because Central Asia is Russian tradition sphere of interest. On the other hand, Russia knows that without the presence of the US in Afghanistan Taliban could come back to power and destabilize whole region.

\section{What does this case mean to the international community?}

It is still painful situation and NATO's societies, especially Americans, are tired of the military operation, but they understand that leaving Afghanistan right now is not the best option. But for NATO countries the situation in their societies is more important than stability in Afghanistan, because Afghanistan is not so close to NATO member states. Of course, we could also speak about stability as a broader definition, when instability in one place affects other places. Anyway, even though countries pay lots of attention to economic issues, the US is seeking to keep some military bases in Afghanistan as an influence tool in the region.

\section{Thank you for your answers.}


Appendix Nr. 5

Interview Nr. 4 Interview with Professor Boris Barkanov, a lecturer in Political Science at West Virginia University (05.03.2014)

1. What were the Russian perception and discourse after NATO's invasion in Kosovo in 1999 ?

I think there was a very broad consensus among Russians, both: between the public and the elite. This was kind an aggression of Western countries and was seen as not a legitimate.

2. How have the Russian perception and discourse changed after 2008 Kosovo declaration of independence?

It did not change so much. It became actually an opportunity for Russia to do the same claims in Abkhazia, South Ossetia.

3. What did it mean to the international community?

In pro-Russian countries anti-NATO mood was rising, but simultaneously in Western countries Kosovo was seen as an expression of people will.

4. How have the Russian perception and discourse changed after NATO's invasion in Libya 2011 ?

I think the Russians focused on how operation in Libya exceeded the UN SC resolution. Specifically they say that it must be non-fly zone but not bombing of troops and ground installations. And also it made Russia more skeptical because no one cooperated with them in UN SC. Finally, some would say that Medvedev did not even care about the conditions in Libya.

5. What did it mean to the international community?

For different international communities it had different meanings. It is hard to see one international community's perception.

6. What are the Russian perception and discourse in current Afghanistan?

I think that Russia has mixed feelings and different groups that emphasize different things. I think on the one hand, Russia is concerned about security in Afghanistan and Islamic fundamentalism. On the other hand, they are not happy long term American presence in Afghanistan Central Asia, so it goes to both directions: they try to deal with securities issues, but they do not want to see NATO staying their longer.

7. What does this case mean to the international community? 
There are security problems what is happening in Afghanistan. It is also the failure of western power when ambitious agenda was not accomplished. The big picture we see is an expansion of NATO power, and now it coming back, decrease.

\section{Thank you for your answers.}


Appendix Nr. 6

Map Nr. 2 NATO transition supply roads to Afghanistan

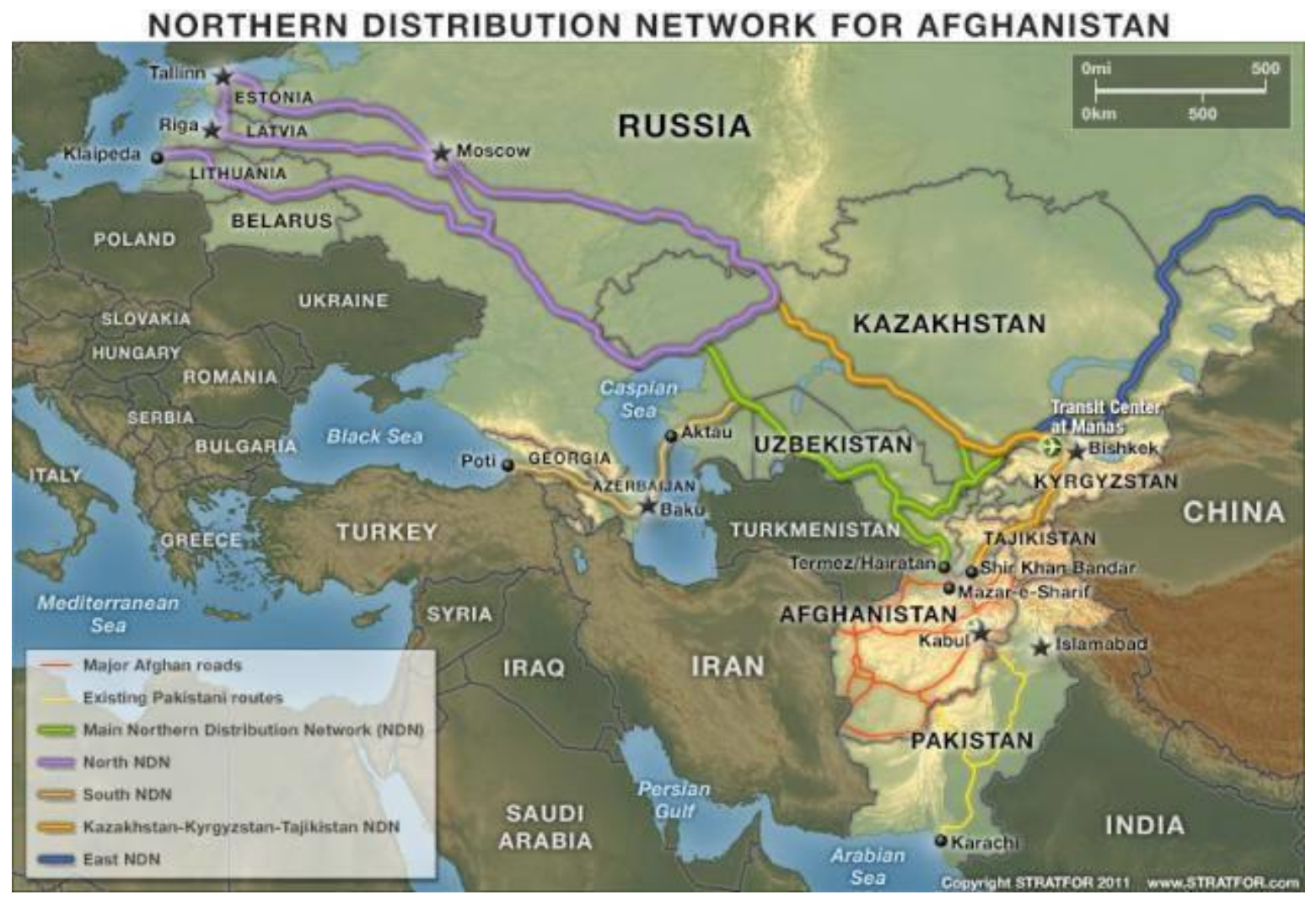

Source: http://www.stratfor.com/sample/analysis/geopolitical-calendar-week-april-7-2014 
Appendix 7

Table Nr. 6 Casualties of NATO forces in Afghanistan

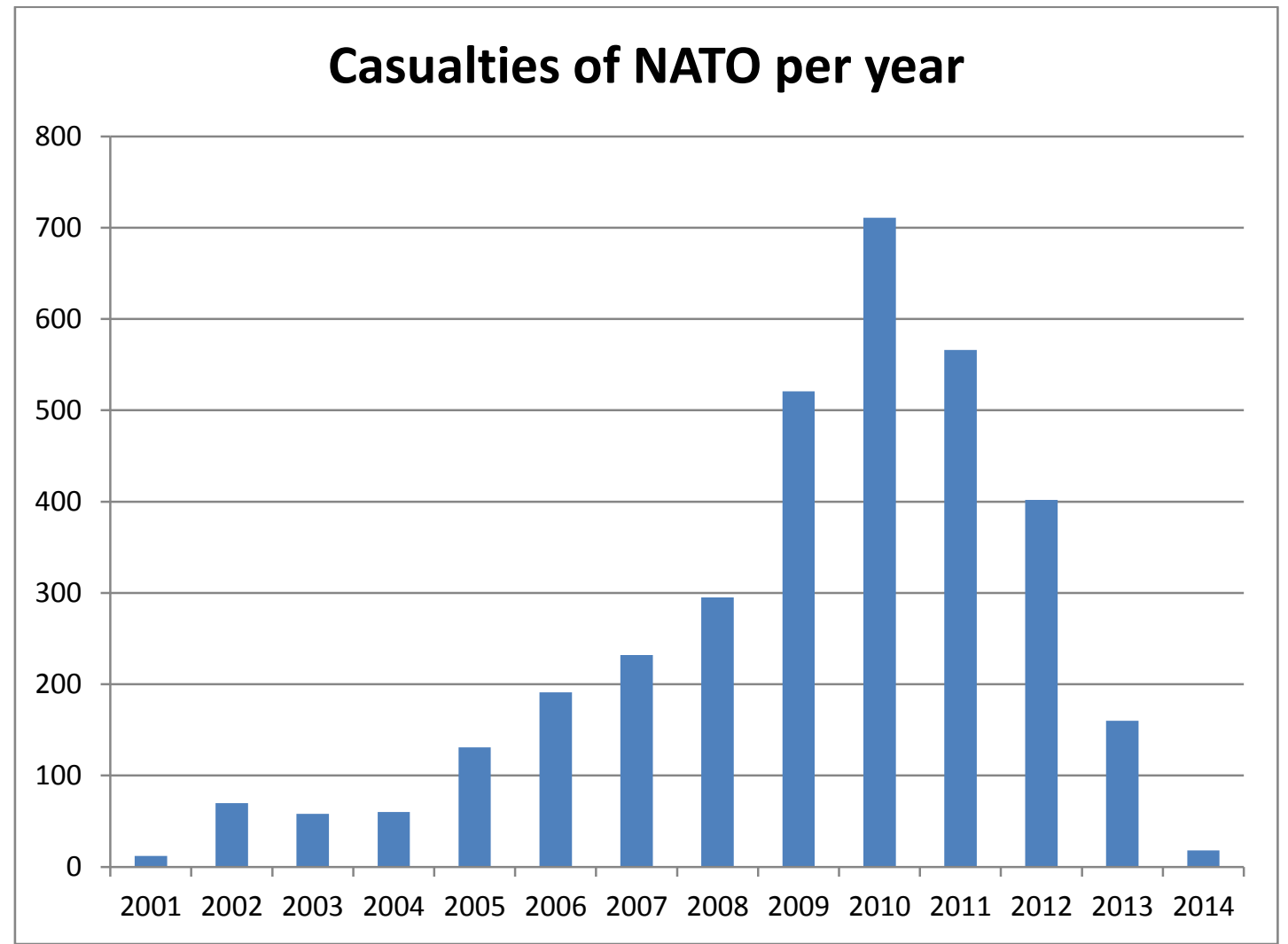

Icasualties.org, The list of the NATO forces casualties in Afghanistan; Source:

http://icasualties.org/oef/ (accessed March 10, 2014) 